\title{
Transparentes de la Nueva España
}

\section{The Transparent of New Spain}

\author{
Martha Fernández \\ Instituto de Investigaciones Estéticas \\ Universidad Nacional Autónoma de México \\ marafermx@yahoo.com
}

Resumen: Los transparentes son vanos abiertos en un retablo o en una portada frente a los cuales se coloca una imagen que, al actuar a contraluz del espectador, se ve rodeada por una mandorla. Fueron un recurso, entre muchos otros, que se utilizaron en el arte barroco para enriquecer las obras y hacerlas más teatrales por medio del manejo de la luz, así como de vanos en forma de estrella con cortinajes y ornamentación abundante. Pero los transparentes también tuvieron una función simbólica de primera importancia que se puede resumir en hacer visible la Jerusalén celestial en la que la sociedad novohispana convirtió sus ciudades y sus recintos religiosos. En este artículo se explica ese significado en los tres tipos de transparentes que se realizaron en la Nueva España: interiores, exteriores y los abiertos en los retablos mayores.

Palabras clave: transparentes, simbolismo, barroco, Nueva España, Jerusalén celestial.

Abstract: $\quad$ The Transparent are open bays in an altarpiece or in a facade in front of which an image is placed that appears to be surrounded by an Aureola, when acting against the backlight to the spectator. They were a resource, among many others, used in Baroque art in order to enrich the works and make them more theatrical by means of light management, as well as windows in the form of stars with curtains and abundant ornamentation. But the Transparent also had a symbolic function of crucial importance that can be summed up in making visible the celestial Jerusalem into which the New Spain society converted its cities and religious enclosures. This article explains this meaning in the three types of Transparent made in New Spain: interior ones, exterior ones, and those opened in the major altarpieces.

Keywords: Transparent, symbolism, baroque, New Spain, heavenly Jerusalem.

Recibido: $\quad 6$ de agosto de 2018 .

Aceptado: 12 de noviembre de 2018. 


\section{Los transparentes}

Como es de todos conocido, el arte barroco era esencialmente teatral y efectista, lo que enriqueció enormemente la arquitectura y la retablística. Portadas, espacios, arcos de triunfo, catafalcos y retablos se convirtieron en escenarios donde se celebraban actos litúrgicos y civiles arropados por contrastes de luz y sombra, tramoyas, recintos semiocultos, misteriosos y sorpresivos. Para conseguir los efectos deseados, los artistas usaron diversos artificios; uno de ellos fue el transparente; el cual consistía en un vano abierto en un retablo o en una portada frente al cual se colocaba una imagen que, al actuar a contraluz del espectador, se veía rodeada por una mandorla.

En los retablos españoles se realizaron dos tipos de transparentes; el primero y más frecuente se situaba en el respaldo de esos muebles y servía para ambientar su imagen titular. El otro consistía "en una ventana alta, que cae angularmente sobre el retablo, favoreciendo su iluminación” (Martín 1995: 118), por ejemplo, el que abrió el arquitecto Narciso Tomé en la catedral de Toledo, considerado el más representativo. ${ }^{1}$ Es preciso aclarar que, en la mayoría de los casos, salvo excepciones como el de la iglesia de San Luis de los Franceses de Sevilla, los transparentes españoles hendidos en los retablos solían abrirse hacia camarines y, por lo mismo, normalmente, solo eran horadados en retablos mayores. La ventana de la catedral de Toledo, en cambio, se abre en la bóveda hacia el exterior, para permitir la entrada de la luz natural que ilumina el retablo del transepto. Algunos, como el de la citada iglesia sevillana, tenían una puerta que se abría y se cerraba, de acuerdo con la liturgia, para hacer todavía más teatral y artificiosa la presencia del transparente (imagen 1).

En la Nueva España no existe ningún ejemplo de transparentes semejante al toledano; en cambio, fueron frecuentes los vanos abiertos en los retablos. Cuando estos se ubican en el primer cuerpo, a manera de respaldo de la imagen titular, siempre se abren, como en España, hacia un camarín. Pero también subsisten otros, todavía más comunes, en los remates de los retablos, que reciben la luz directamente del exterior, y estos no solo los encontramos en retablos mayores, sino también en los levantados a lo largo de las naves. En las portadas era lo mismo, solo que las imágenes se colocaban frente a una ventana abierta hacia el interior de las iglesias.

1 Realizado por el arquitecto y escultor Narciso Tomé de 1729 a 1732. 


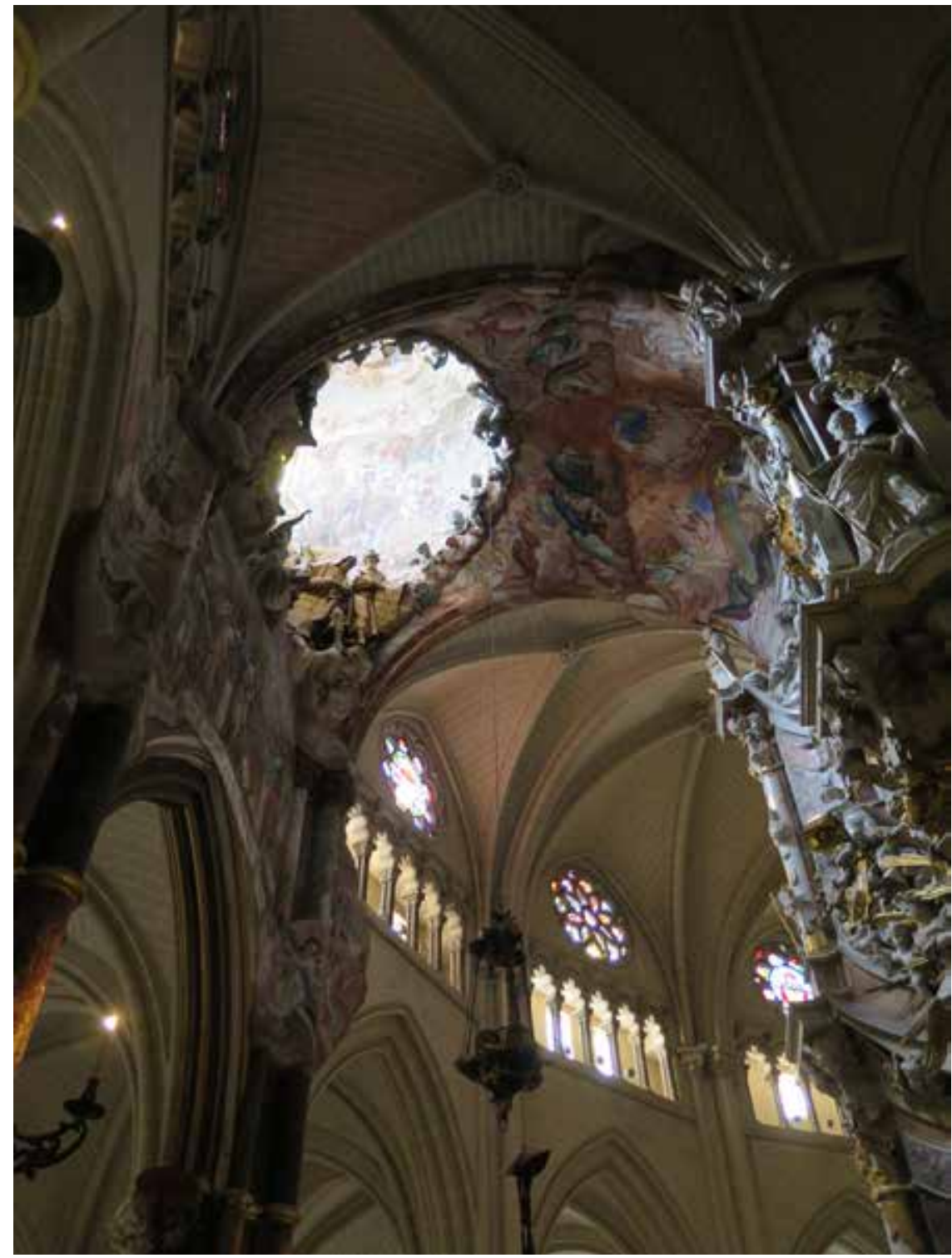

IMAGEN 1: Transparente de la catedral de Toledo, España. Foto: Martha Fernández

En todos los casos, la teatralidad barroca es innegable, pero lo importante es el significado simbólico que encierra este recurso y del que me ocuparé en el presente artículo. Como es obvio, los transparentes tienen que ver, antes 
que nada, con la luz; comenzaré, entonces, por repasar la importancia que esta tuvo en la arquitectura barroca de la Nueva España.

\section{La luz en las iglesias barrocas novohispanas}

Como he tenido ocasión de exponer en otros estudios, desde el punto de vista simbólico, la luz ha sido identificada con la divinidad desde la más remota antigüedad; de ahí surgió el culto al sol en todas las culturas: en Egipto era Ra; en Grecia, Helio, y en el Imperio romano, el Sol invictus, que siempre triunfa sobre la oscuridad (Fernández 2011a: 159-186). ${ }^{2}$

En el cristianismo ocurrió lo mismo: las interpretaciones que se llevaron a cabo del Antiguo Testamento tendieron a ser consideradas como prefiguras del Nuevo: es decir, de la cultura cristiana y en él son numerosas las citas que relacionan a Yahvé con la luz. Por ejemplo, en el Salmo 104, Gloria de Dios en la creación, se dice de Él: "Envuelto de luz como de un manto; / despliegas los cielos como una tienda..." (Salmos 104: 2).3 Obviamente, en el Nuevo Testamento, Cristo también fue asociado con la luz: "Yo soy la luz del mundo; el que me sigue no anda en tinieblas, sino que tendrá luz de vida", como se afirma en el Evangelio de Juan (Juan 8:12). De acuerdo con Juan Francisco Esteban Lorente, la identificación de Cristo con el Sol es clara desde el siglo IV "cuando se cristianizó el solsticio de invierno con la fiesta del Nacimiento, pues el 25 de diciembre era la conmemoración pagana del Nacimiento del Sol Invicto-Mitra" (Esteban 1998: 99).4 El sustento científico a la centralidad simbólica del Sol lo proporcionaron las teorías de Nicolás Copérnico (1473-1543), confirmadas más tarde por Galileo Galilei (1554-1642). Ellas, aunadas al racionalismo renacentista, cercano a la cultura grecolatina, coadyuvaron para que la luz del Sol fuera incorporada a los espacios arquitectónicos como imagen de Dios.

Durante el desarrollo de la cultura barroca el manejo de la luz tuvo un papel preponderante en las soluciones espaciales, no solamente desde el punto de vista formal, sino también y de manera muy particular, para transmitir valores simbólicos. Así pues, se construyeron espacios por donde se

2 En ese estudio amplío lo relativo a los antecedentes teóricos y simbólicos desde la Antigüedad hasta el Renacimiento.

3 Las citas bíblicas fueron tomadas de la versión de la Sagrada Biblia (Nácar 1964).

4 De acuerdo con el autor, quienes más interés tuvieron en lograr la sustitución de Mitra por Cristo fueron Zenón, obispo de Verona (363-372) y Marbod de Rennes (1035-1123). 
ingresaba a iglesias o capillas cuyos vestíbulos tenían uno o dos tramos oscuros para desembocar después en salas de oración bañadas de la luz que proporcionaba la cúpula (imagen del cielo), como, por ejemplo, en la capilla del Rosario del convento de Santo Domingo en la ciudad de Puebla ${ }^{5}$ (imagen 2) y en la iglesia de Nuestra Señora de Loreto de la ciudad de México. ${ }^{6}$ Otros recursos arquitectónicos para conseguir efectos de claroscuro fueron las almohadillas con las que "adornaron" edificios como la fachada del templo de San José de Gracia, ${ }^{7}$ el antiguo claustro del oratorio de San Felipe Neri, "el Viejo" ${ }^{8}$ y la portada lateral de la parroquia de Santa Catalina, ${ }^{9}$ todos en la ciudad de México.

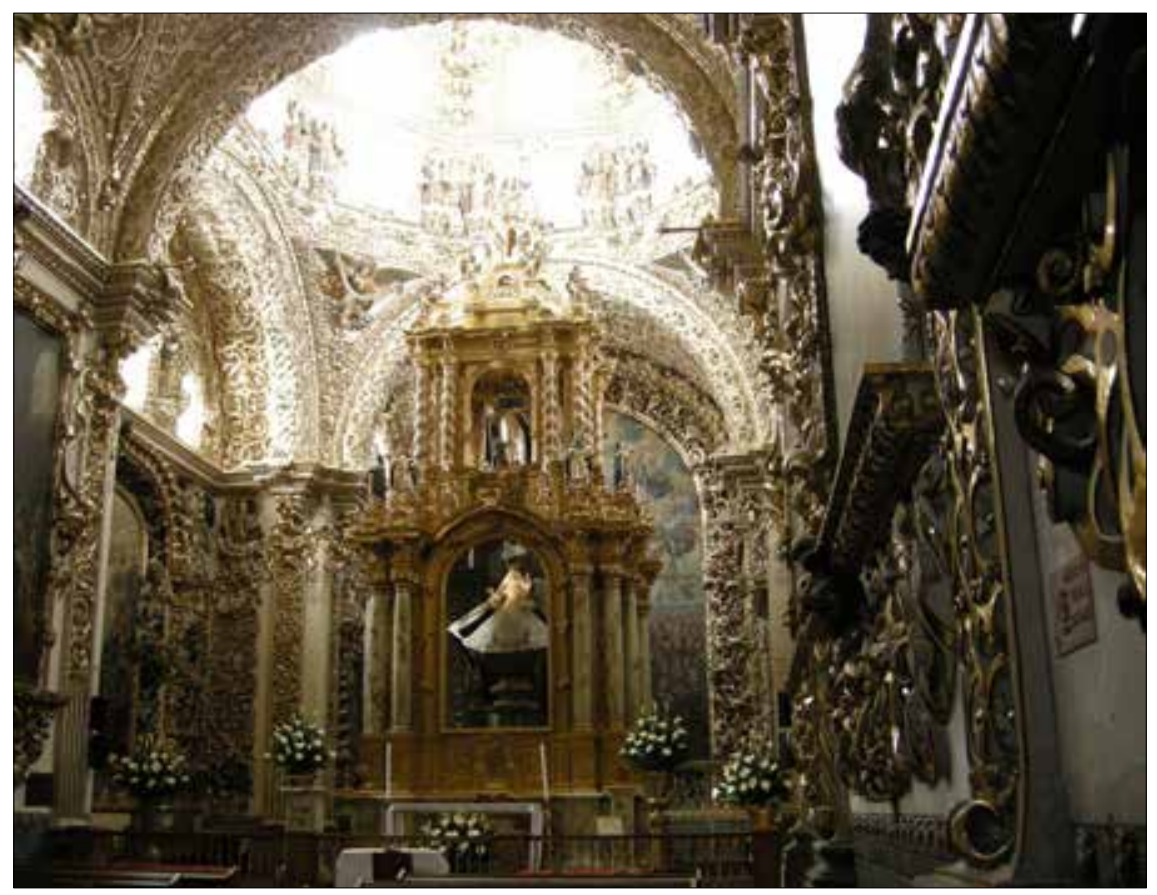

Imagen 2: Capilla del Rosario, iglesia de Santo Domingo, ciudad de Puebla. Foto: Martha Fernández

5 Inaugurada el año de 1692.

6 Construida por los arquitectos Ignacio Castera y Agustín Paz de 1809 a 1816. Pese a que en esa época se desarrollaba también el arte neoclásico, incluso en esta iglesia la portada y la cúpula lo son, su planta y su disposición espacial son todavía barrocas.

7 Construida a mediados del siglo XVII y atribuida al arquitecto Diego de los Santos y Ávila el Viejo.

8 Construido el año de 1684 por el arquitecto Cristóbal de Medina Vargas.

9 Construida de 1691 a 1692 y atribuida al arquitecto Cristóbal de Medina Vargas. 
Sin embargo, es de reconocerse que la mayor parte de los espacios religiosos de la Nueva España tuvieron una luminosidad uniforme a lo largo de las naves, gracias a la identificación de la luz del Sol con la luz de Cristo: así como la luz que entraba a las iglesias era la luz de Dios, se prefería tener espacios luminosos que permitieran apreciarla y sentirla (Fernández 2011a: 170-186).

Igualmente, los retablos dorados que se levantaron en las iglesias no tuvieron solamente fines estéticos, sino principalmente simbólicos. Uno de ellos fue reflejar la luz del Sol en el oro, es decir, la luz de Dios; con esa misma finalidad se realizaron también retablos con espejos, como el del noviciado del ex convento de San Francisco Javier, en Tepotzotlán, Estado de México, y el de la Virgen del Rosario en el santuario de Jesús Nazareno, en Atotonilco, Guanajuato, ambos del siglo XVIII (Fernández 2011 b: 305-328; Fernández 2011c: 329-364) (imagen 3).

Es decir que, en la Nueva España, a partir del desarrollo de la cultura barroca, la luz tuvo un papel de primera importancia para hacer sentir la presencia de Dios en los espacios sagrados.

\section{La Jerusalén celestial}

El friso de la portada principal del templo de San Juan Bautista de Coyoacán, en la ciudad de México, tiene grabada una cita en latín que dice: "No está aquí algo distinto, sino la Casa de Dios y la Puerta del Cielo. Génesis 28". ${ }^{\circ 0}$ Es la referencia al sueño de Jacob, cuando durmió sobre una piedra, en el que tuvo la visión de una escalera que llegaba al cieloy por la que subían y bajaban ángeles; al despertar se dio cuenta de que, en efecto, ese lugar era "la Casa de Dios y la Puerta de los cielos", por lo que lo llamó Betel, "aunque la ciudad se llamó primero Luz”, según dice el libro bíblico. Ungió la piedra donde durmió con aceite y la convirtió en un altar (Génesis 28: 1-22). Es decir que, como afirma Jean Hani, el templo puede ser considerado como una puerta abierta al "Más Allá" (Hani 2000: 76), lo que se refuerza en la cita del Evangelio de Juan en la que Cristo afirma: "Yo soy la puerta; el que por mí entrare se salvará..." (Juan 10:9).

De esta manera, la puerta de un templo nos indica que al ingresar a él no solamente se traspasa un vano, sino se transita de un mundo a otro; del mundo profano al mundo sagrado; de la tierra al cielo. Todo templo y todo arte es sagrado en la medida en que reproduce arquetipos celestiales, por lo

10 "NONESTHICALDNISIDOMVSDEIEPORTACOLEI. GEN 28”. 


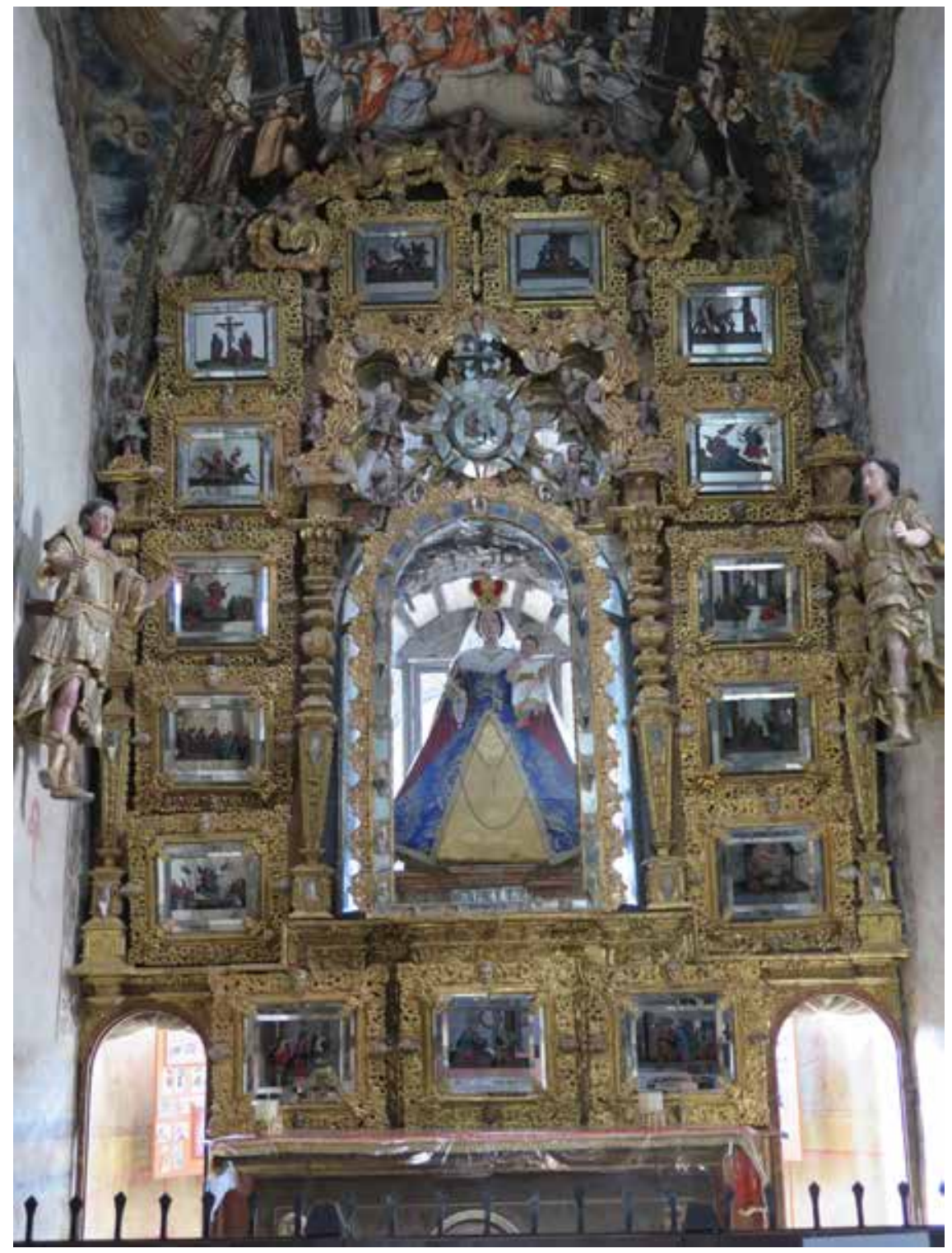

IMAGEN 3. Retablo de la capilla del Rosario del santuario de Jesús Nazareno, Atotonilco, Guanajuato. Foto: Martha Fernández

que Hani explica que el arte sagrado es "como una prolongación de la Encarnación, del descenso de lo divino en lo creado", pero no "por la intención subjetiva del artista, sino por su contenido objetivo; y este no es, por su parte, 
más que el conjunto de representaciones que corresponden, en el campo de las formas sensibles, a leyes cósmicas que expresan principios universales". Por ello, el autor citado advierte que "el carácter esencial del arte sagrado es el de ser simbólico, es decir, el de traducir mediante imágenes polivalentes la correspondencia que relaciona entre sí los diversos órdenes de realidad, el de expresar, mediante lo visible, lo invisible, y el de conducir al hombre hacia este" (Hani 2000: 12-13).

En ese sentido, todo templo sagrado posee múltiples significados simbólicos: es la imagen del cosmos y del mundo; es también la casa de Dios, lugar central de la hierofanía, pero también entendida como la reproducción terrena de su palacio celestial, cuya planta y forma fue revelado a los hombres por medio de ángeles o profetas, es decir, sus mensajeros. En la tradición judeocristiana, el santuario revelado es el conocido genéricamente como Templo de Salomón, aunque en realidad el concepto incluye dos templos revelados: uno a Moisés, constituido por una tienda de telas y pieles, descrito en el libro del Éxodo (2731 ), y el templo de piedra, edificado por el rey Salomón y explicado en dos textos bíblicos: el Libro primero de los Reyes (6-8) y el segundo de Crónicas (3-6).

En el cristianismo, además, el templo es también el cuerpo de Cristo, representado desde la época medieval de manera literal por medio de las plantas de cruz latina, es decir, su cuerpo crucificado. Cabe recordar otra cita de san Juan en la que el evangelista recuerda cuando Jesús dijo: "Destruid este templo y en tres días lo levantaré. Replicaron los judíos: cuarenta y seis años se han empleado en edificar este templo, ¿y tú vas a levantarlo en tres días? Pero Él hablaba del templo de Su cuerpo" (Juan 2:19-21). Como puntualiza Jean Hani, "el templo representa, para la congregación cristiana, el Cuerpo de Cristo, pero, como el Cuerpo de Cristo lo es también la propia congregación, esta última constituye el templo espiritual, el Cuerpo místico de Cristo". A lo que se agrega que el alma de cada fiel también es ese templo, de donde se concluye que, en realidad, "el edificio sagrado puede ser considerado... desde un triple punto de vista: como la Humanidad de Cristo, como la Iglesia y como el alma de cada fiel, siendo estos tres puntos de vista, por otra parte, indisociables, porque los dos últimos no son sino consecuencia del primero" (Hani 2000: 47). Según Juan Antonio Ramírez, también existió una asimilación cultural entre el cuerpo de Cristo y el Templo de Salomón, de manera que, "los planos de aquella arquitectura perfecta, inspirados por Dios a Salomón, tendrían que haber reproducido, de alguna manera, la naturaleza humana de Jesús..." (Ramírez 2003: 15-16). 
El templo es también el paraíso donde habita Dios, su ciudad. El paraíso cristiano es la Jerusalén celestial descrita en los capítulos 21 y 22 del Apocalipsis, y es este simbolismo el que más interesa para los fines de este artículo. Para comprender el proceso mediante el cual un templo se convierte simbólicamente en ese paraíso cito nuevamente a Hani, quien advierte que, en la medida en que el templo es construido como un lugar sagrado, su objetivo se amplía, pues: ya no es solo el de "congregar a los fieles", sino el de crear para ellos una atmósfera que permita que la Gracia se manifieste mejor, y lo alcanza en la medida en que logra tirar hacia sí, canalizar adentro, en un sutil juego de influencias, con un objetivo -la comunión con lo Divino- el flujo de sensaciones, sentimientos e ideas [...] el santuario, decimos, es un "instrumento" de recogimiento, de gozo, de sacrificio y de elevación (Hani 2000: 13).

Por ello, los arquitectos y los artistas en general utilizaron elementos simbólicos como la luz para crear esa atmósfera de trascendencia que transportaba a los fieles a una realidad distinta y superior; en este caso, a la Jerusalén celestial.

Como mencioné, los textos del Antiguo Testamento fueron considerados anticipaciones del Nuevo, es así como la Jerusalén celestial descrita en el Apocalipsis tiene su antecedente en la descripción de la Nueva Jerusalén escrita por el profeta Ezequiel desde su exilio en Egipto. En su visión también apocalíptica, imagina la nueva ciudad a la que regresarían los judíos después de la destrucción de la antigua Jerusalén y de su Templo sagrado, el año de 586 a. C. (Ezequiel 40-43). Según el profeta, la ciudad santa, la Nueva Jerusalén, era el Templo mismo, de manera que "los que la habitasen... gozarán de una intimidad perfecta con Dios; el pecado será vencido y la muerte aniquilada en la victoria”, como explica Karen Armstrong (1997: 201). De acuerdo con esta idea, la ciudad se encontraba en un "monte altísimo" y estaba amurallada. Su forma era cúbica, por lo que tenía cuatro puertas de acceso ubicadas hacia los cuatro puntos cardinales, a las que se accedía por medio de siete gradas. "El templo interior y los vestíbulos del atrio, el umbral, las ventanas aspilleradas, las portadas, todo el trono; los tres pisos estaban cubiertos de madera" y tanto el exterior como el interior del templo se encontraban tapizados con relieves, "representando querubines y palmas" (Ezequiel 41:15-18). Ezequiel también relató cómo vio "la gloria de Dios de Israel venir del oriente" y le dijo: "Hijo del hombre, este es el lugar de mi trono, el escabel de las plantas de mis pies, donde habitaré para siempre en medio de los hijos de Israel" (Ezequiel 43: 1-7). 
En el Apocalipsis del Nuevo Testamento, Juan tuvo una visión parecida, pues también vislumbró una ciudad-templo, pero con la diferencia fundamental de que este autor vio a Jesús identificado con el mismo Dios sentado en el trono celestial, por lo que escribió: "Y no vi templo en ella. Por cuanto el Señor Dios omnipotente es su templo, con el Cordero". Esta ciudad, que descendió del cielo "de parte de Dios, que tenía la Gloria de Dios", también es de forma cúbica con "doce mil estadios de circuito, siendo iguales su longitud, su latitud y su altura”. Está rodeada por un muro "grande y alto" de jaspe, constituido por doce hiladas de piedras preciosas, en los que se encuentran los nombres de "los doce apóstoles del cordero". Para ingresar a ella existen doce puertas, cada una de las cuales es una perla, que se abren a cada uno de los cuatro puntos cardinales, distribuidas de tres en tres; en ellas, se encuentran doce ángeles y los nombres de las doce tribus de Israel. La ciudad es "de oro puro, semejante al vidrio puro" y su plaza, "de oro puro, como vidrio transparente". Juan, además, contempló una ciudad luminosa porque "la gloria de Dios la iluminaba y su lumbrera era el Cordero". En esa ciudad existe "un río de agua de vida, clara como el cristal", que sale del trono de Dios y del Cordero; finalmente, en cada borde de ese arroyo el autor vio "un árbol de vida que daba doce frutos, cada fruto en un mes, y las hojas del árbol eran saludables para las naciones" (Apocalipsis 21: 1-27; 22: 1-2).

\section{Transparentes interiores}

Aunque la entrada de la luz de Dios en las iglesias es suficiente para justificar la existencia de los transparentes en los remates de los retablos cabe aclarar que, en el imaginario novohispano, sus ciudades y pueblos eran también una Jerusalén celestial en la tierra, y sobre ello existen múltiples referencias. Se puede recordar, a manera de ejemplo, que, en 1648, el cronista guadalupano Miguel Sánchez escribió: "me persuado, que como el demonio dragón tan expulso del cielo no puede volver al cielo a inquietar a la ciudad del cielo, ni a sus hijos los ángeles, halla en México... una nueva ciudad de Jerusalén, ciudad de paz, bajada del cielo..." (Sánchez 1648, reproducido en Torre 1999: 176-177). Incluso, ese autor llegó a relacionar a la Virgen de Guadalupe con la del Apocalipsis y afirmó que al contemplar a la imagen novohispana, "se me representaba la imagen, que el evangelista san Juan, en el capítulo doce de su Apocalipsis, vio pintada en el cielo, y deseaba con mi pluma, a un mismo tiempo crear aquestas dos imágenes, para que la piedad cristiana contempla- 
se en la imagen del cielo el original por profecía, y en la imagen de la tierra el trasunto por milagro..." (Torre 1999: 157) de forma tal que la "mujer vestida de sol” era México, pues "todos conocen que aquesta tierra se tuvo por inhabitable, por ser región tan vecina al sol” (Torre 1999: 165); la luna bajo sus pies era también la propia ciudad, "por lo natural fundada sobre aguas, en que predomina la luna” (Torre 1999: 167); las doce estrellas que coronaban la cabeza de la Virgen, "es el sol que la viste, y esta mujer México vive amparada, honrada y favorecida debajo de esta corona" (Torre 1999: 167). Esto es que, según Sánchez, gracias a la Virgen, la ciudad de México se convirtió en una Jerusalén celestial terrena.

Del mismo modo, y gracias a esta relación establecida entre la Jerusalén celestial y la ciudad de México, esta fue concebida en el imaginario de los novohispanos como una ciudad amurallada que tenía cuatro baluartes que la flanqueaban y defendían en los cuatro puntos cardinales, bastiones que eran cuatro advocaciones de la Virgen María. El primer autor en referirse a ellos fue fray Francisco de Florencia, quien en su obra titulada La Estrella del Norte de México, publicada el año de 1688, explicó:

quiere esta Señora tanto a esta ciudad de México, y en ella a toda la Nueva España, que parece que se ha puesto, como su amparo seguro en las cuatro partes de México, en cuatro imágenes milagrosas suyas, que le sirven de cuatro castillos roqueros que la defiendan... $\mathrm{Al}$ oriente, $\mathrm{N}$. Señora de la Bala, que sabe recibir en sí las balas, porque no hieran a quien della se vale. Al poniente, a la Virgen de los Remedios, que está hecha a cegar y derribar por tierra a sus enemigos. A la de la Piedad, que con su hijo difunto en los brazos está llorando nuestros delitos y aplacando a Dios por nuestras culpas, al sur. La de Guadalupe al norte, que como estrella fija nos guía y alumbra: que, como la principal de todas, se ha puesto al septentrión, porque de él dice la Escritura, que amenaza todo el mal..." (Florencia 1785: 90-91, reproducido en Torre 1999: 394-395).

Igualmente, en la muy conocida leyenda fundacional de la ciudad de Puebla, estructurada en 1746 por Diego Antonio Bermúdez de Castro, fueron ángeles los que la midieron y la trazaron, igual que en la Jerusalén descrita en el Apocalipsis, donde un ángel "tenía una medida, una caña de oro, para medir

"Sobre los baluartes también escribieron: Cayetano Cabrera y Quintero, Escudo de Armas de México (1746) y Mariano Fernández de Echeverría y Veytia, Baluartes de México (publicado hasta 1820). 
la ciudad, sus puertas y su muro" (Apocalipsis 21: 15). Gracias a este paralelismo, el cronista concluyó que

siendo esa dichosa ciudad tan parecida esta de la Puebla, y habiendo sido los que midieron sus calles no otros que de la misma especie del que por orden del Altísimo niveló la sagrada Seón, se puede con mediano discurso inferir la hermosura que tendrá esta Ciudad Angélica por sus bien dispuestas calles, hermosos templos, ricas casas, y oficinas con su forma y figura cuadrada (Bermúdez 1985: 148).

Esas relaciones entre las ciudades y la Jerusalén celestial son especialmente significativas para comprender la importancia de los transparentes novohispanos, pues si la luz que ingresaba a las iglesias era la de Dios, se entiende que esta no provenía solamente del cielo, sino de la misma ciudad, de la Jerusalén novohispana, iluminada por la gloria de Dios y del Cordero, tal como se describe en el Apocalipsis.

Debo decir que, de acuerdo con Carlos Borromeo, no era recomendable abrir ventanas en los retablos; así lo manifestó en su tratado Instrucciones de la fábrica y del ajuar eclesiásticos (1577), donde advirtió que se tuviera precaución de que “... las ventanas de la pared posterior no ocupen alguna parte de cualquier altar, ni siquiera mínima: sobre todo que no miren en línea recta al altar que está cerca de la misma pared, o que, efectivamente, de algún modo estén sobre el altar" (Borromeo 1985: 12-14). Sin embargo, en la Nueva España se convirtió en tradición abrir ventanas en los retablos de iglesias y capillas.

Desde mi punto de vista, esa costumbre se propició a partir del diseño de la catedral de México. Como he comentado en otros estudios, el proyecto original del maestro Claudio de Arciniega contemplaba un edificio que tenía las tres naves centrales a la misma altura y un poco más bajas las dos naves de capillas. Esta solución provocaba que solo se pudieran abrir ventanas en lo alto de las naves procesionales y en las capillas, pero no en la nave mayor, que sería la más oscura (Fernández 2015a: 97-103). Entre los años de 1635 y 1640, el arquitecto Juan Gómez de Trasmonte llevó a cabo un rediseño del edificio y una de las soluciones que implementó fue la de darle a cada una de las naves del edificio una altura distinta para que todas recibieran iluminación de manera directa (Fernández 2015b: 123-139), pero obviamente no suprimió las ventanas de las capillas que se abren hacia el exterior, precisamente en el sitio 
en el que se podían colocar, y se colocaron, los retablos mayores. Es decir que, pese a las indicaciones de Carlos Borromeo, las condiciones arquitectónicas de la Catedral impusieron la necesidad de abrir ventanas en los retablos, las cuales por su altura coincidieron con los remates de esos muebles. Esta solución, que parecería propia solo de la catedral de México, trascendió a toda la Nueva España por tratarse del templo más importante, donde se encontraba la cátedra del arzobispo y donde se manifestaron todas las posibilidades artísticas y simbólicas de los edificios religiosos posteriores.

En algunos de los retablos de la catedral de México realizados a finales del siglo XVII y durante el siglo XVIII, los artistas aprovecharon las ventanas de las naves de capillas para convertirlos en transparentes; de ellos, conservamos dos: el mayor de la capilla de Nuestra Señora de la Soledad ${ }^{12}$ y el mayor de la capilla de San José13 (imagen 4). En el primero, la imagen que se encuentra en la ventana es una cruz contemporánea al retablo, ${ }^{14} \mathrm{y}$ eso tiene que ver con el origen de la cofradía de la Santa Cruz. Hacia el año de 1657, don Fernando Altamirano, conde de Santiago de Calimaya, siendo mayordomo de la fábrica material de la catedral de México, solicitó "en su nombre, y en el de los maestros y principales obreros que trabajaban en ella... se designase aquella capilla ofreciendo adornarla a su costa", lo que el virrey duque de Alburquerque le concedió (Marroqui 1903: III, 454), pero al carecer de recursos suficientes para levantar un retablo, los operarios colocaron en ella una gran cruz de madera que se dedicó el 15 de agosto de ese mismo año (Toussaint 1973: 157; Fernández 1985: 59)..$^{15}$ Hacia 1670-168o, pudieron construir el retablo que conocemos, dedicado a Nuestra Señora de la Soledad, y colocaron la cruz torneada que todavía vemos en su ventana. El dato es importante porque puede tratarse de uno de los transparentes más tempranos de la Nueva España. En el retablo de San José la imagen que se encuentra en el transparente es la de Santa Brígida, escultura igualmente contemporánea al retablo, es decir, de la segunda mitad del siglo XVIII. ${ }^{16}$

12 No se conoce la fecha exacta de su construcción, pero se calcula que fue levantado alrededor de 1670-1680.

13 Realizado en la segunda mitad del siglo XVIII.

14 El transparente no se aprecia ahora debido a los vitrales color ámbar diseñados por el maestro Mathías Göeritz a mediados del siglo XX.

15 A partir de entonces, se estableció a la Santa Cruz como patrona de la cofradía de arquitectos, albañiles, canteros y de todos los artistas dedicados a la construcción.

16 En esta capilla tampoco se aprecia ahora el transparente debido a la presencia de los vitrales del maestro Mathías Göeritz. 


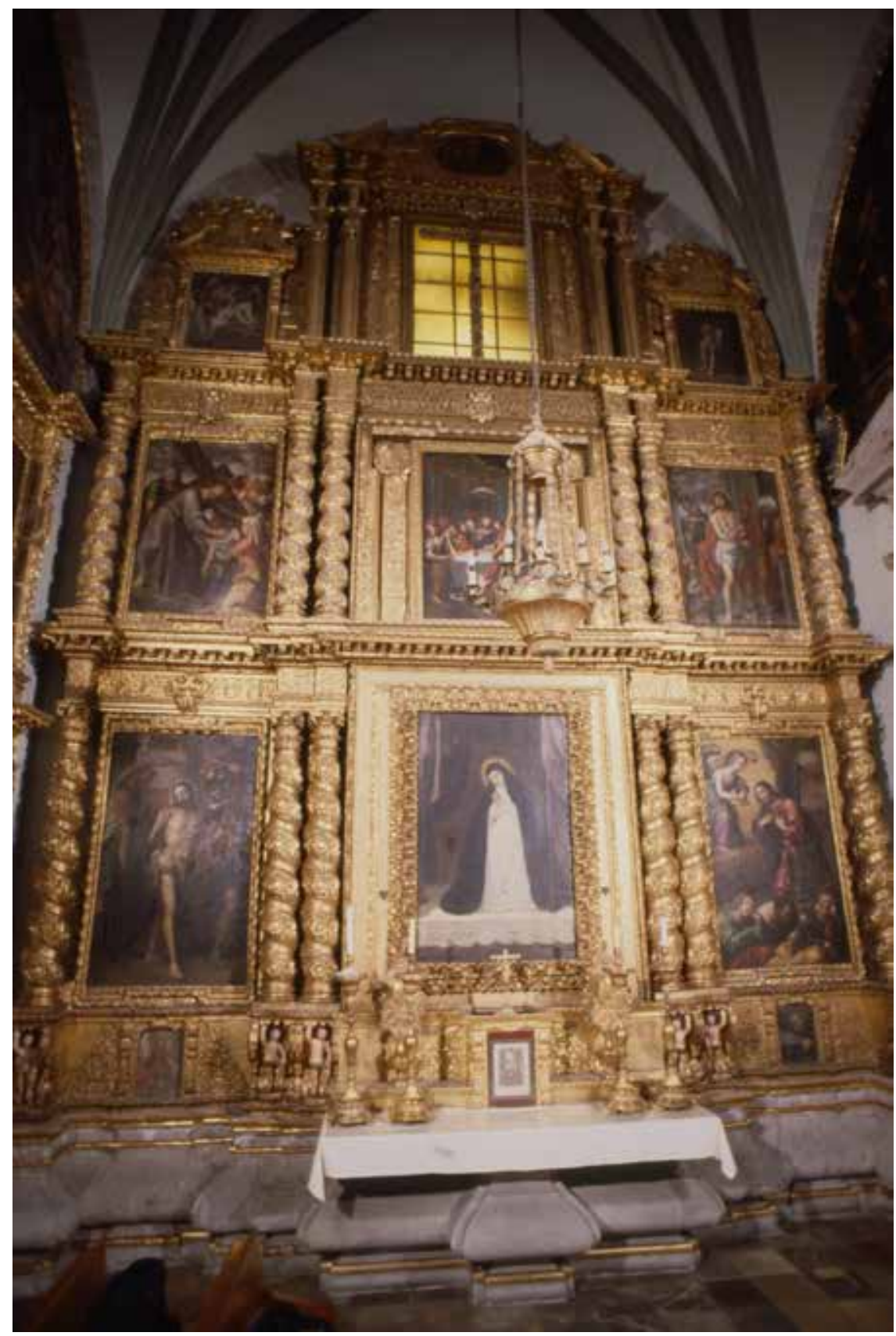

IMAGEN 4: Retablo mayor de la capilla de Nuestra Señora de la Soledad de la catedral de México. Foto: Archivo Fotográfico "Manuel Toussaint", Instituto de Investigaciones Estéticas, Universidad Nacional Autónoma de México. 
A lo largo del territorio de lo que fue la Nueva España podemos encontrar una gran cantidad de retablos con transparentes en sus remates, para lo cual fue necesario abrir ventanas, tanto en los retablos de los ábsides, como en los de los muros laterales; entre los primeros podemos citar el retablo mayor de la parroquia de Dolores Hidalgo en Guanajuato (imagen 5) y el de la parroquia de San José de Chiapa en Puebla, ambos del siglo XVIII. ${ }^{17}$ Algunos de los que se abrieron en los muros laterales, en esa misma época, son los del crucero de la iglesia de Santo Domingo en la ciudad de Zacatecas, dedicados a san Ignacio de Loyola y san Francisco Xavier (imagen 6$) ; ;^{18}$ los retablos dedicados a la Dolorosa y a san Juan Nepomuceno en la iglesia de Santa Clara, de la ciudad de Querétaro ${ }^{19}$ (imagen 7), así como el retablo de san José de la iglesia de San Agustín, en la ciudad de Salamanca, Guanajuato. ${ }^{20}$ Muchos otros perdieron las imágenes con las que se constituían los transparentes, como el mayor de la parroquia de Apan, Hidalgo, y los laterales de la iglesia de San Francisco Xavier en Tepotzotlán, Estado de México, ${ }^{21}$ pero como se conservan las peanas que las soportaban, se comprende que también formaron ese recurso simbólico.

\section{Transparentes exteriores}

Durante el siglo XVIII, se adoptó la costumbre de colocar imágenes frente a las ventanas que se abrían en las portadas de las iglesias. Su significado simbólico es el mismo que poseen los transparentes interiores, solo que, en este caso, la luz viene del interior del recinto sagrado. En este punto, cabe recordar

${ }_{17}$ En el transparente del retablo mayor de la iglesia de San José de Chiapa, en Puebla, se colocó, seguramente en el siglo xx, un vitral con la mandorla pintada para hacerla todavía más obvia.

${ }^{18}$ La iglesia perteneció originalmente a la Compañía de Jesús, pero cuando los jesuitas fueron expulsados de los territorios de España el año de 1767, el edificio fue entregado a la Orden de Santo Domingo. El retablo mayor (desaparecido) y los dos del crucero fueron contratados por Felipe de Ureña y Juan García Castañeda el 3 de junio de 1747 (Halcón 2012: 86).

19 El retablo de Nuestra Señora de los Dolores fue realizado por Francisco Martínez Gudiño en 1765. El retablo de san Juan Nepomuceno fue realizado por Pedro José de Rojas hacia el año de 1740, aunque el proyecto pudo haber sido realizado por el ensamblador Luis Ramos Franco (Ramírez 2005: 221, 227).

${ }^{20}$ Levantado el siglo XVIII.

${ }^{21}$ El retablo mayor y los dos del crucero fueron contratados por Miguel Cabrera e Higino Chávez el 7 de diciembre de 1753. Los restantes de la nave se realizaron entre 1754 y 1757 y se atribuyen a los mismos autores (Tovar de Teresa 1995: I: 192, 260). 


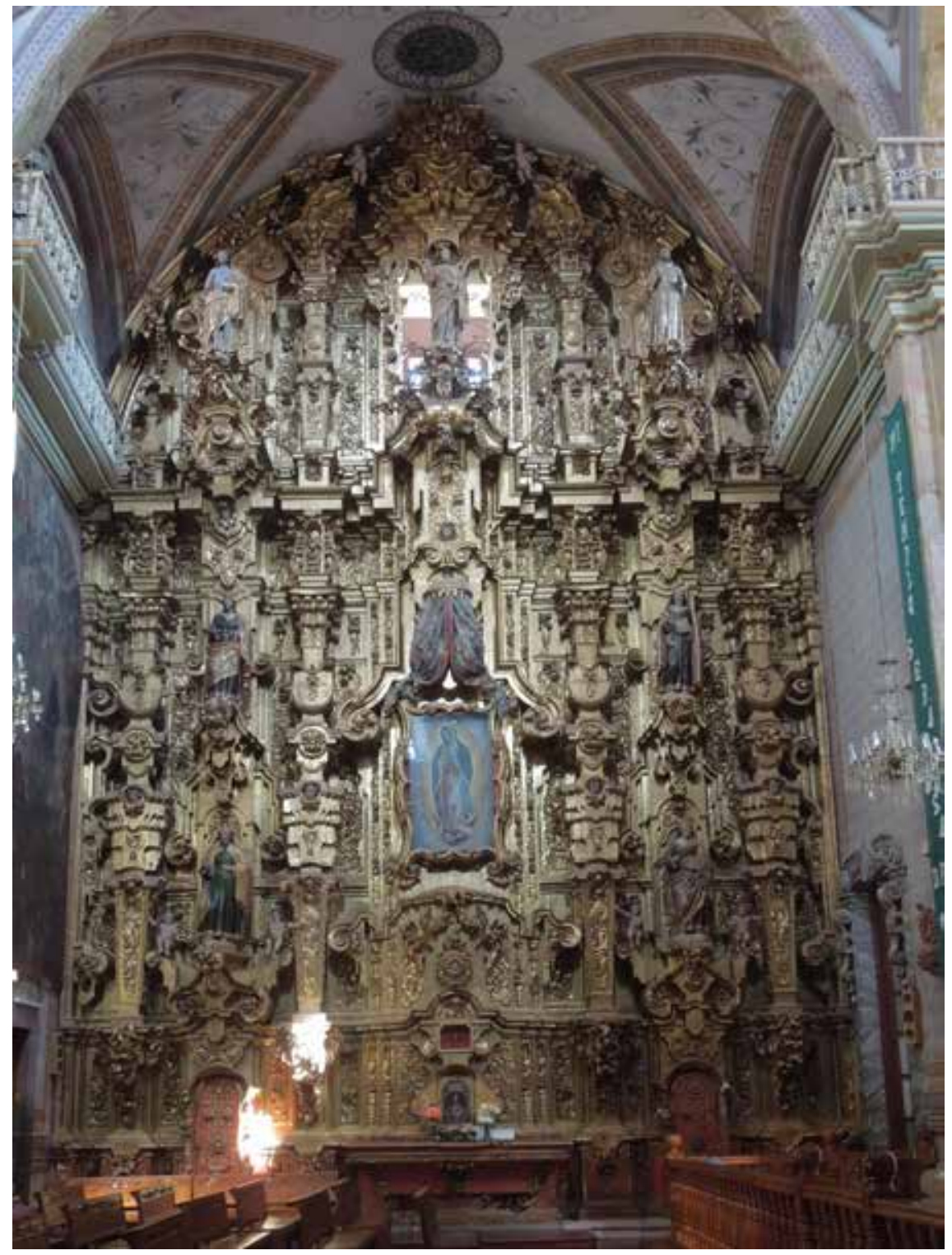

IMAGEN 5: Retablo mayor de la parroquia de Nuestra Señora de los Dolores, Dolores Hidalgo, Guanajuato. Foto: Martha Fernández 
FERnÁNDEZ | Transparentes de la Nueva España

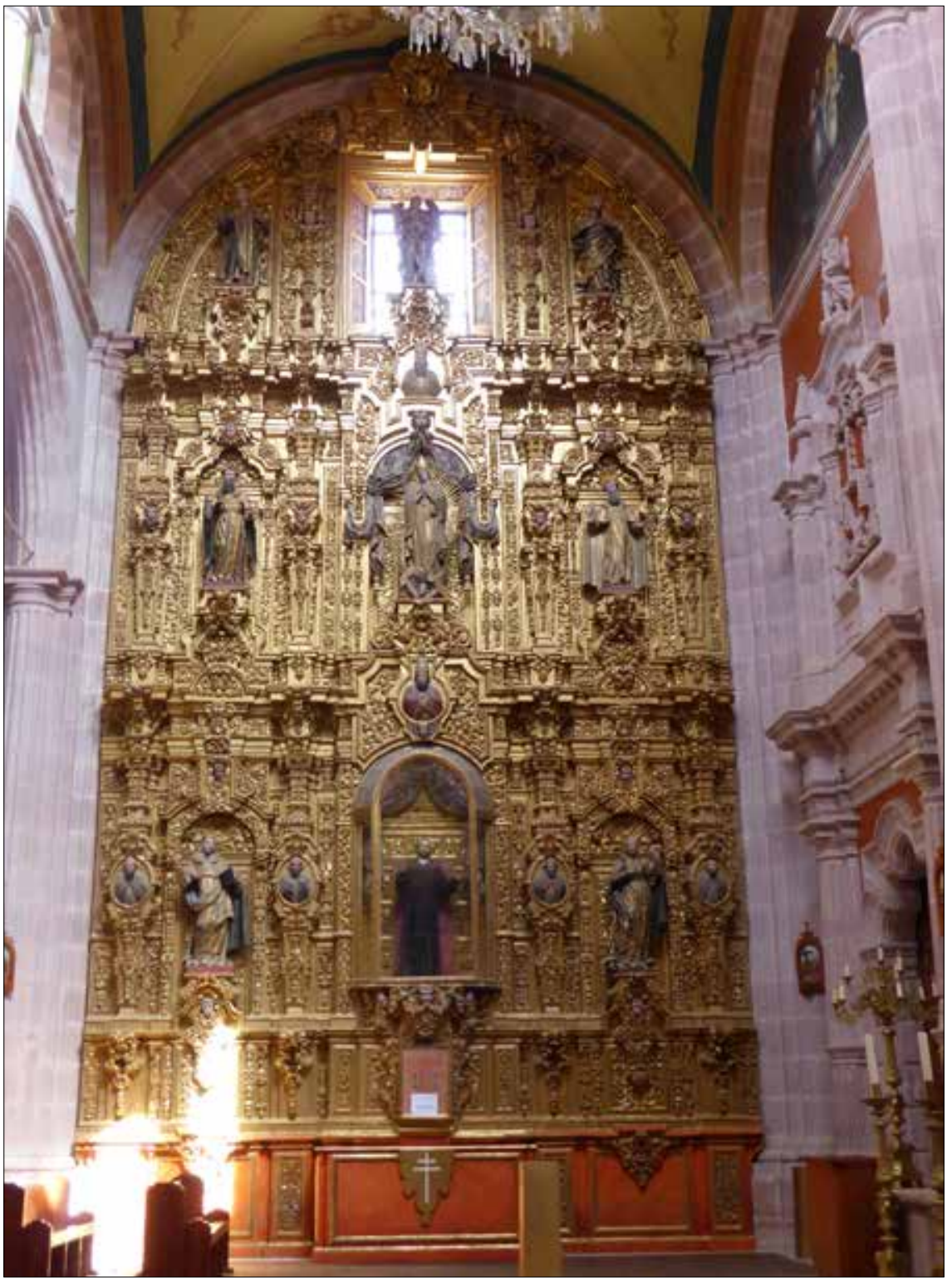

ImAGEN 6: Retablo del crucero de la iglesia de Santo Domingo, ciudad de Zacatecas. Foto: Martha Fernández 


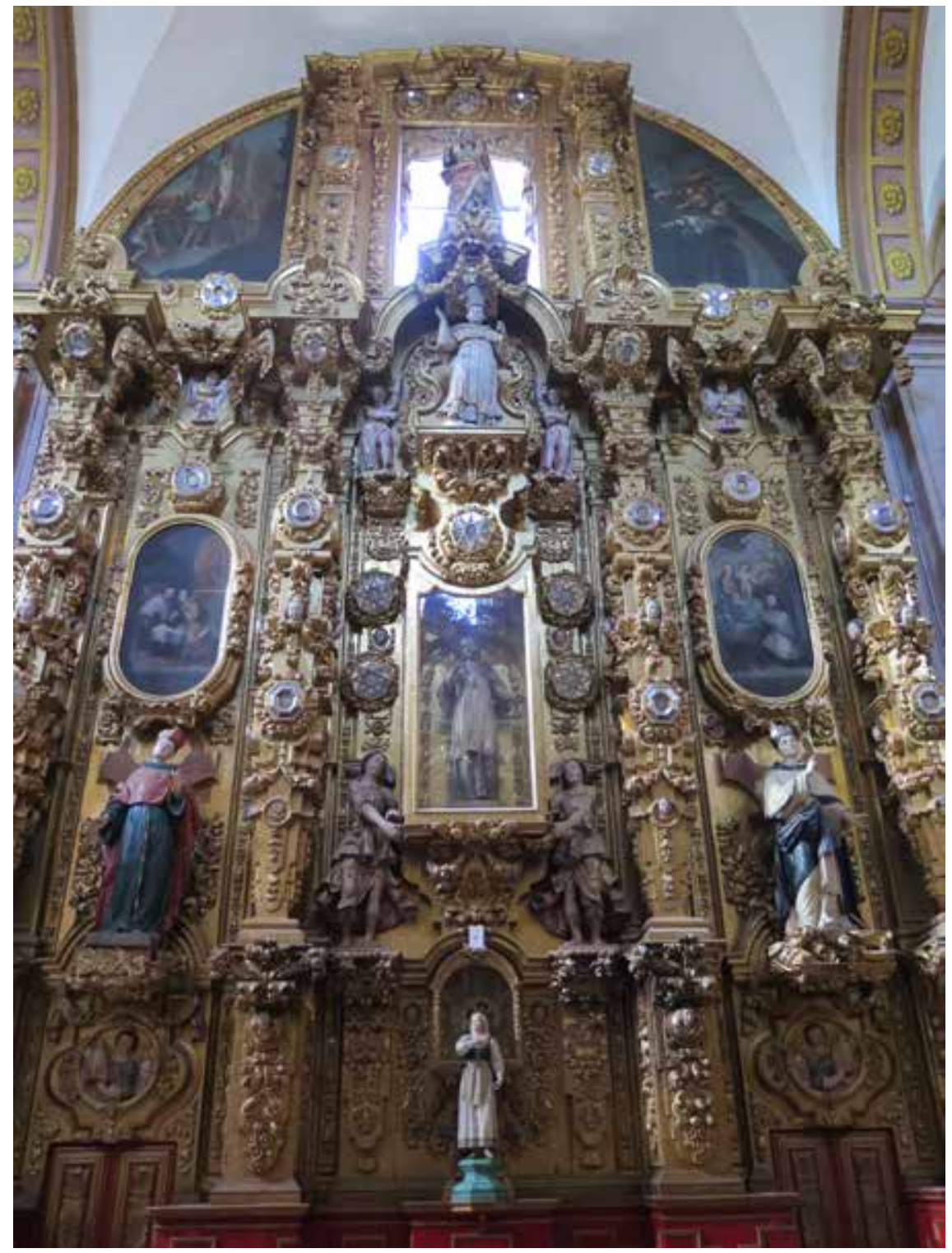

IMAGEN 7: Retablo de San Juan Nepomuceno, iglesia de Santa Clara, ciudad de Querétaro. Foto: Martha Fernández 
la cita del Apocalipsis en la que dice de la Jerusalén celestial que "su muro era de jaspe, y la ciudad de oro puro, semejante al vidrio puro" (Apocalipsis 21:18), mientras que su plaza "era de oro puro, como vidrio transparente" (Apocalipsis 21:21). Es ahí donde cobran sentido los retablos dorados de los templos. ${ }^{22}$ Aunque simbólicamente todo templo cristiano, tenga o no ese tipo de muebles, refieren conceptualmente a la Jerusalén celestial, como vimos antes; los retablos dorados son elementos que contribuyen de manera muy significativa a crear ese ambiente de trascendencia, la atmósfera que permite la comunión con lo divino, como afirma Jean Hani; son la manifestación física de la ciudad de oro y logran evidenciar que lo que hay detrás de las ventanas es la Jerusalén celestial y la luz que emana de ella es la luz de Cristo, quien, como se afirma en el Apocalipsis, estaba sentado en el trono celestial; la gloria de Dios la ilumina y su lumbrera es el Cordero. Desde luego, se tiene que considerar que esta luz no es física, sino simbólica, como corresponde al arte sagrado.

La vinculación entre los retablos y la Jerusalén celestial está explicada en un Sermón Panegírico que escribió Juan Antonio de Nájera y Enciso el año de 1755, cuando se estrenó el retablo mayor de la iglesia del convento de monjas de Nuestra Señora de Regina Coeli de la Ciudad de México, dedicado al Ecce Homo. ${ }^{23}$ De acuerdo con el autor, (imagen 8)

Aquella Jerusalén tenía cuatro Ángulos y hoy María está entre los cuatro místicos Ángulos que son los Evangelistas: allá eran doce las puertas, porque son doce allá y acá los Apóstoles. Ángeles allá esas puertas, y acá sirven de guarda, y defensa de ese Retablo ese bien concertado número de alados serafines. Doce piedras preciosas eran las que servían allá de fundamentos, y adorno, y acá adornan ese Colateral otras doce preciosas piedras, que tienen las mismas prerrogativas, que aquellas; porque allí se ostenta Joseph místico Crisolito, que sabe deshacer los temores, resplandeciendo como un cristal, sin dejar en su elevada Santidad las folideces de oro; allí está Rita con el color rubio en la parte superior, que es la frente, ensangrentada con la espina de la Corona del Redentor, con el color negro de su vestido, y la blancura de su pureza, que son los

${ }^{22}$ De acuerdo con textos escriturarios, el Templo de Salomón también tenía los muros y el artesonado de su techumbre cubiertos con planchas de cedro talladas con diferentes motivos y bañados de oro. De manera que los retablos dorados de las iglesias cristianas también son una referencia al Templo hierosolimitano (1 Reyes, 6-8 y 2 Crónicas, 3-6).

${ }_{23}$ Aunque este retablo no tiene transparente y perdió la escultura del Ecce Homo. 
distintivos de el Sardonio [sardónice]: y si el Sardio tiene color de carne, y se cría en el corazón de una piedra, Gertrudis habita y se transforma en el Corazón de la mejor piedra, que es Cristo. El Zafiro tiene unas puntas de oro, que lucen como rayos de una estrella, y la piedra jaspe tiene unas manchas como llagas, señas bien individuales de Domingo y de San Francisco; el Berilo da valor para resistir los combates, siendo más hermoso cuando tiene menos adorno; y quien viendo resplandecer entre la pobreza a Joaquín, resistiendo los combates, e improperios de su ancianidad, dejará de colocarlo en el Berilo Topacio quiere decir lo mismo que buscado, reconócenlo los Lapidarios por Madre de la Esmeralda, y así Ana buscada, y hallada por el mismo Dios para madre de la más preciosa Esmeralda, que es María, es sin controversia el Topacio. Una de las propiedades fabulosas de la Esmeralda es ahuyentar los Demonios, contrayendo enemistad perpetua con los halagos de Venus, prerrogativas todas verdaderas del Abad Antonio. El Ameristo, que lo es Francisco Javier, desprende del mismo pecho unas llamas. El Calcedonio es la piedra más proporcionada para un Sello; por eso, como Protectores del Sacramental Sigilo San Juan Nepomuceno y San Gil Abad, relucen como el Calcedonio. Es el jacinto antídoto contra los venenos,

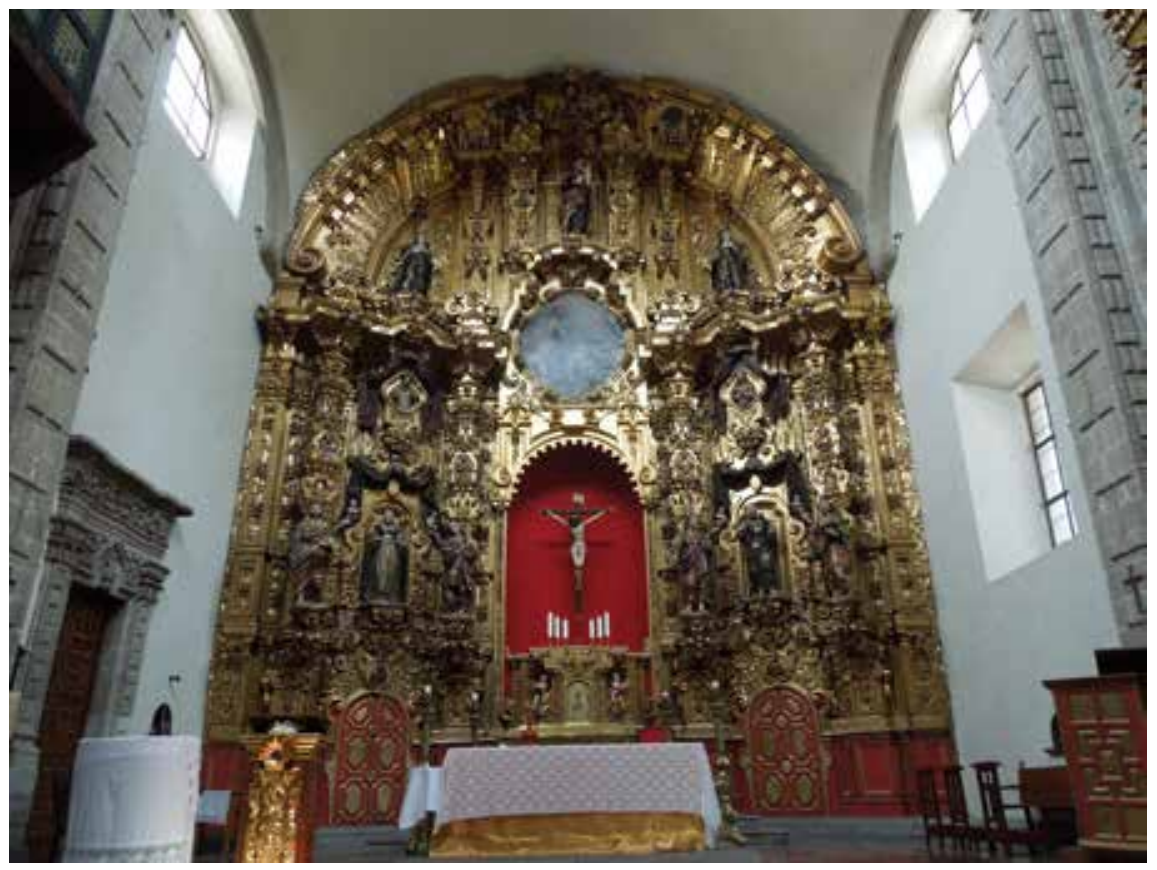

ImAGen 8: Retablo mayor de la iglesia de Nuestra Señora de Regina Coeli, Ciudad de México. Foto: Martha Fernández 
y medicina de las enfermedades, y para esto claman los milagros, y portentos de Paduano Antonio. Engendra el Crisopraso liberalidad, y desprecio de las riquezas del mundo; y desprecio a este, con la Corona, y el Cetro de Francia, la augusta Santa Juana de Valois.

Y concluye con la referencia directa a Cristo, concretamente al Ecce Homo, a quien estaba dedicado el retablo:

Toda la preciosidad de estas piedras concurre que salga verdaderamente precioso, y aseado el fundamento, que lo es sin controversia Jesús, como que esta Piedra preciosa, y aseada ... o este Cristo caracterizado con el título de aseado sea el fundamento en que estriba y donde asienta la Mística Jerusalén, que es María Reina del Cielo Regina Coeli en su venturosa Natividad. Dirémoslo más claro, es Cristo fundamento de María, porque toda su grandeza se funda en ser Trono y Altar, que se dedica, y prepara para que en él haga su habitación el mismo Cristo, sirviéndole también de Tabernáculo, a esa misma Inmensa Majestad ... Todo lo tenemos en el Altar, y todo lo encontramos en la Mística Jerusalén; que si en esta vio el Evangelista a un Ilustre Personaje con una caña que era medida ... acá también; pero no nos detengamos: Ecce Homo, ahí le tenemos, a ese Dios Hombre con esa caña, vara, o medida por donde deben regularse los Comercios, que afianzan su seguridad, y sus creces en la misma medida, y protección de esta caña. Pues ya tenemos a la vista la dedicación de un Altar donde se deposita el mismo Dios, como en Mística Jerusalén, admirando las mismas circunstancias de la dedicación del de Israel (Nájera 1755, reproducido en Tovar 1988: II, 314-318). ${ }^{24}$

Nájera y Enciso se refería a las doce hiladas de piedras preciosas que forman los muros de la Jerusalén celestial, de acuerdo con el Apocalipsis: "la primera, de jaspe; la segunda, de zafiro; la tercera, de calcedonia; la cuarta, de esmeralda; la quinta, de sardónica; la sexta, de cornalina; la séptima, de crisolito; la octava, de berilo; la novena, de topacio; la décima de crisoprasa; la undécima, de jacinto, y la duodécima, de amatista” (Apocalipsis 21: 19-20). Solo que en el retablo esas piedras son los santos que se encuentran representados ahí y, por supuesto, el mismo Jesús en su advocación de Ecce Homo, lo que

24 El Ecce Homo ha desaparecido. De acuerdo con Tovar de Teresa, el retablo fue contratado por el pintor Francisco Martínez el 18 de julio de 1754. 
de todas maneras no se aparta de la descripción de la Jerusalén apocalíptica, pues, como apunté, "el muro de la ciudad tenía doce hiladas, y sobre ellas los nombres de los doce apóstoles del Cordero" (Apocalipsis 21: 14), es decir, también en los textos bíblicos las piedras preciosas estaban relacionadas con seres humanos, con santos vinculados a Cristo, quien dijo al fundador de su Iglesia: "Yo te digo a ti que tú eres Pedro, y sobre esta piedra edificaré yo mi Iglesia" (Mateo 16: 18).

Entre las portadas en las que se colocaron imágenes frente a ventanas, podemos citar, a manera de ejemplo, las principales de dos templos guadalupanos: el de Aguascalientes ${ }^{25}$ (imagen 9) y el de San Luis Potosí: ${ }^{26}$ igualmente, la portada central del santuario de Nuestra Señora de Ocotlán ${ }^{27}$ (imagen 10) y la de la iglesia de San Nicolás de Bari en Panotla, ${ }^{28}$ ambos en el actual estado de Tlaxcala. En la Ciudad de México, son varios los templos que todavía conservan sus imágenes frente a las ventanas de sus portadas, entre ellos: la iglesia de San Lorenzo ${ }^{29}$ (imagen 11) y la de Nuestra Señora del Pilar, la Enseñanza Antigua; ${ }^{30}$ además, todas las portadas de la capilla del Pocito, en la villa de Guadalupe. ${ }^{31}$ En la capilla de la Purísima Concepción del Salto del Agua $^{32}$ se puede ver la peana que sostenía una imagen, de la que pende una guardamalleta de tres puntas, pero por desgracia la escultura desapareció. En los modelos citados, se pueden destacar, además, dos elementos de gran importancia para el barroco y para el simbolismo de las iglesias como imágenes de la Jerusalén celestial: la forma de las ventanas y los cortinajes que se abren para enmarcar las imágenes.

25 La portada principal de la parroquia corresponde a la construcción original que fue realizada de 1767 a 1789 (Angulo Îñiguez 1945-1950, II: 778).

26 La iglesia fue construida por el arquitecto Felipe Cleere de 1772 a 1800 (Vargas Lugo 1986: 221).

27 Portada del siglo XVIII.

28 La iglesia fue fundada el año de 1693. En la base de la torre existe una inscripción con la fecha de 1796, época a la que debe corresponder su portada.

29 La iglesia fue construida por los arquitectos Juan Gómez de Trasmonte y Juan Serrano a partir de 1643 y fue bendecida el año de 1650 (Fernández 1985: 85). La portada fue edificada por el arquitecto José Joaquín García de Torres a partir de 1779 (Bazarte Martínez 2001: 291).

30 Construida de 1772 a 1778 y atribuida al arquitecto Ignacio Castera (García 2005: 320-343).

${ }^{31}$ Edificio construido por el arquitecto Francisco Antonio Guerrero y Torres de 1777 a 1792 (González-Polo 2006: 149-159).

32 La capilla fue construida de 1750 a 1770 (García 2004: 239). 
FERNÁNDEZ | Transparentes de la Nueva España

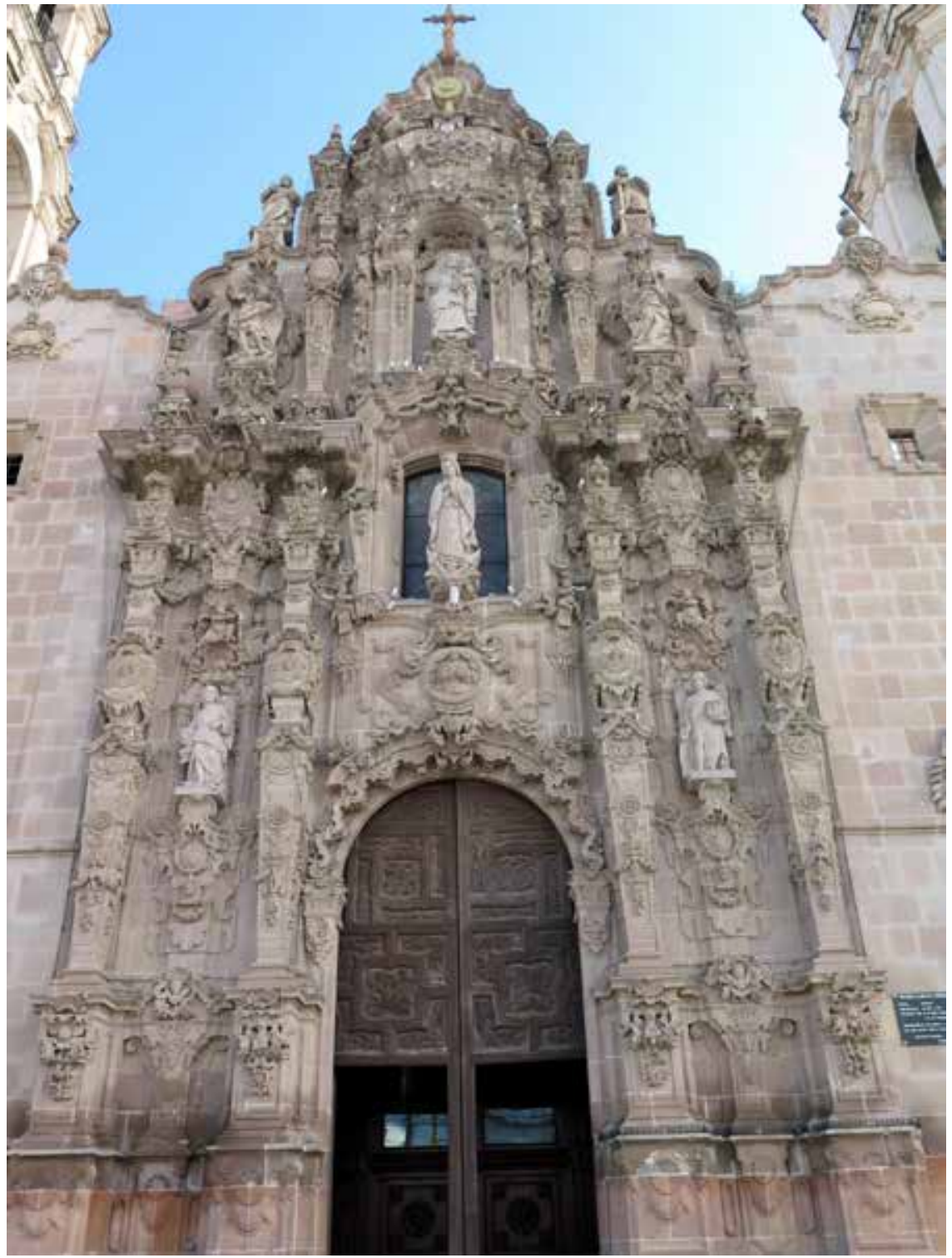

IMAGEN 9: Portada principal de la iglesia de Nuestra Señora de Guadalupe, ciudad de Aguascalientes. Foto: Martha Fernández 


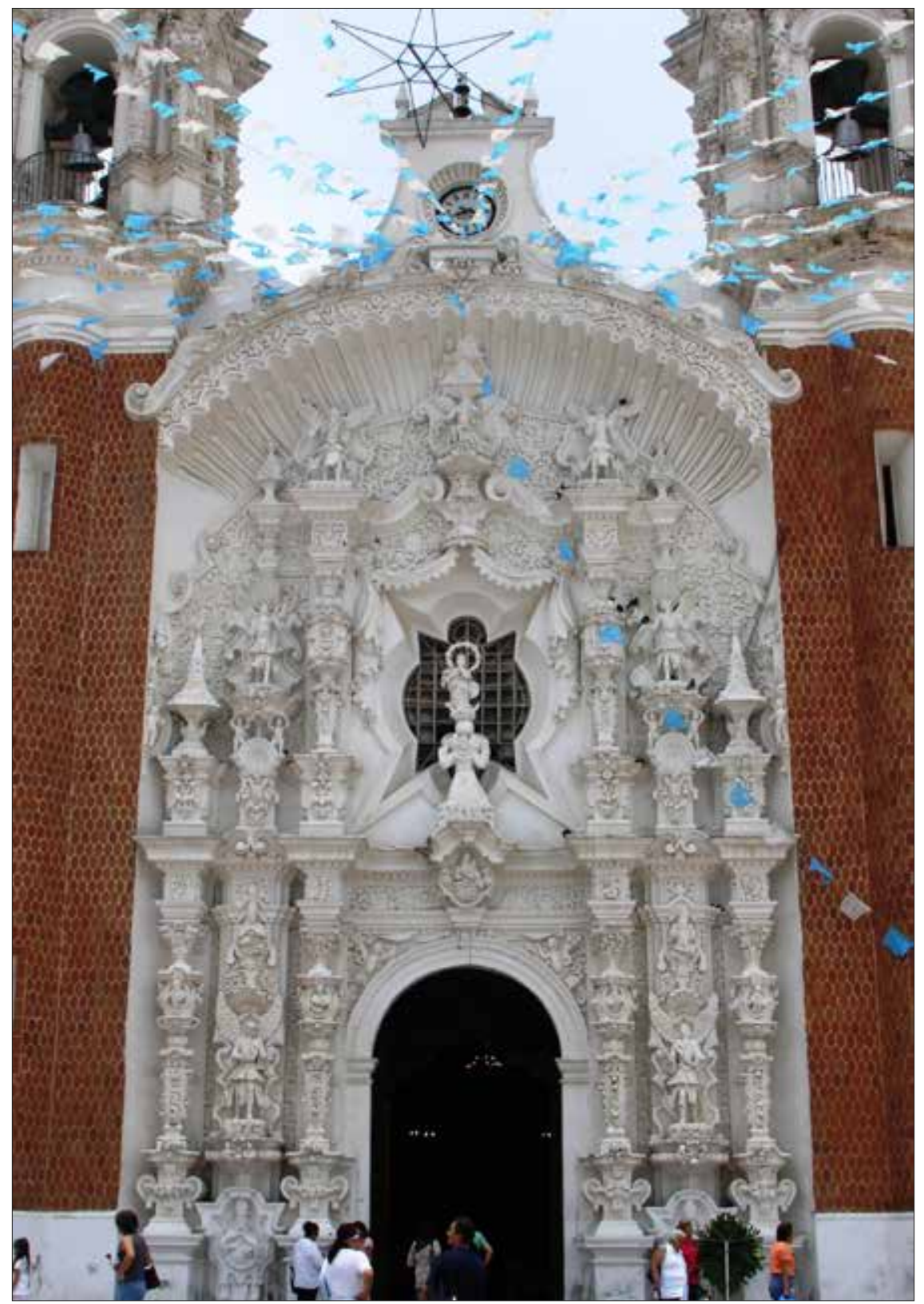

IMAGEN 10: Portada principal del santuario de Nuestra Señora de Ocotlán, Tlaxcala. Foto: Martha Fernández 
FERnÁNDEZ | Transparentes de la Nueva España

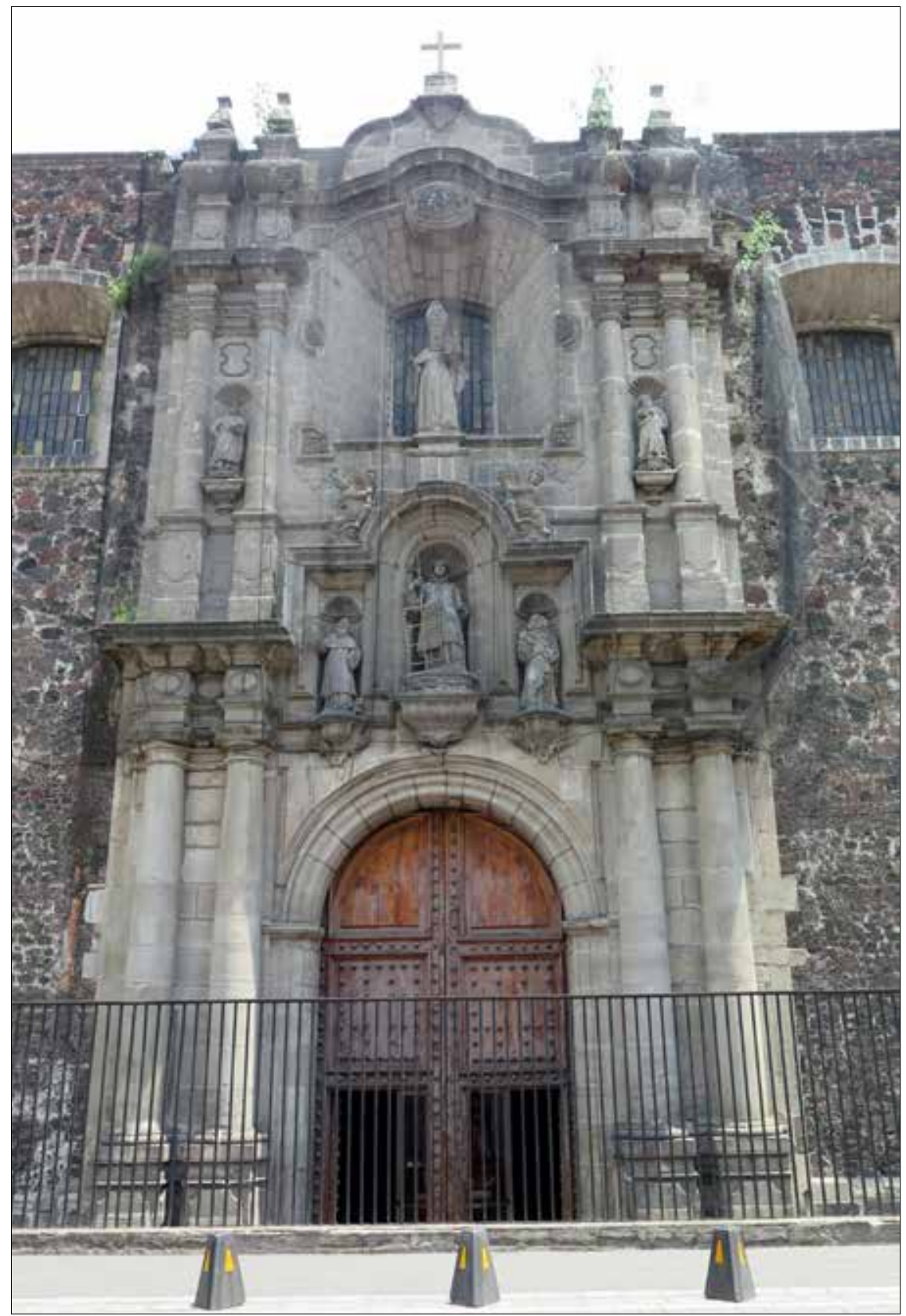

ImAGen 11: Portada de la iglesia de San Lorenzo, Ciudad de México. Foto: Martha Fernández 
Como se aprecia, la forma de las ventanas es variada, pero se repite la estrella; es natural, pues la sola presencia de un elemento de esa naturaleza nos indica que estamos viendo el cielo, o una ventana que se abre hacia el cielo, hacia la Jerusalén celestial que constituye el recinto sagrado; literalmente, "la casa de Dios y la puerta del cielo". En la mayor parte de las iglesias citadas, las imágenes que se colocaron frente a las ventanas son las titulares, salvo la de la iglesia de San Lorenzo, en la que se alojó la imagen de San Agustín, porque el convento al que pertenecía el recinto era de monjas agustinas. Sin embargo, merece la pena detenernos en la capilla del Pocito de la villa de Guadalupe.

Lo primero que se debe apuntar es que las ventanas de sus tres portadas tienen forma de estrella (imagen 12). Lógicamente, la imagen de la Virgen de Guadalupe se encuentra en la portada principal y, para hacer más clara la idea de que estamos viendo "la puerta del cielo", se encuentra rodeada por una muy abundante ornamentación a base de hojas, roleos, filacterias, ángeles y una corona en el vértice de la estrella, obviamente relacionada con "la coronación de la Virgen" en el paraíso, acto que llevó a cabo la Trinidad, esto es, las tres personas de Dios: Padre, Hijo y Espíritu Santo, una vez que María fue elevada a los cielos. En las portadas laterales, en cambio, se colocaron frente a las ventanas cruces torcidas que — pienso- intentan imitar los troncos de los árboles, porque la cruz de Cristo es el árbol de la vida en la cultura cristiana y también está relacionado con el "árbol de vida" colocado a cada lado del río en la Jerusalén celestial, "que daba doce frutos, cada fruto en un mes, y las hojas del árbol era saludable para las naciones”, según la descripción del Apocalipsis (Apocalipsis 22:2) (imagen 13).

Respecto a las cortinas que se abren como marco de las imágenes, concretamente en los templos de Panotla y Ocotlán (imagen 14), desde luego, hacen de las portadas una especie de escenografía, como si de telones de teatro se tratara, aunque en su significado simbólico redunda nuevamente en la imagen del cielo. ${ }^{33}$ En el Antiguo Testamento se hace referencia a él como una tienda; concretamente Isaías así lo plantea cuando afirma que Yahvé "tiende los cielos como un toldo / y los despliega como una tienda de morada" (Isaías 40:22); incluso al inicio de este artículo vimos cómo en el Salmo 104 se afirma

33 La ventana de la iglesia de Guadalupe, en Aguascalientes, tiene una moldura doble curvada que da la impresión de ser una cortina enrollada. En algunos retablos, como en el citado de San Juan Nepomuceno de la iglesia de Santa Clara de Querétaro, también se hicieron cortinas con tela encolada y tienen el mismo significado simbólico. 


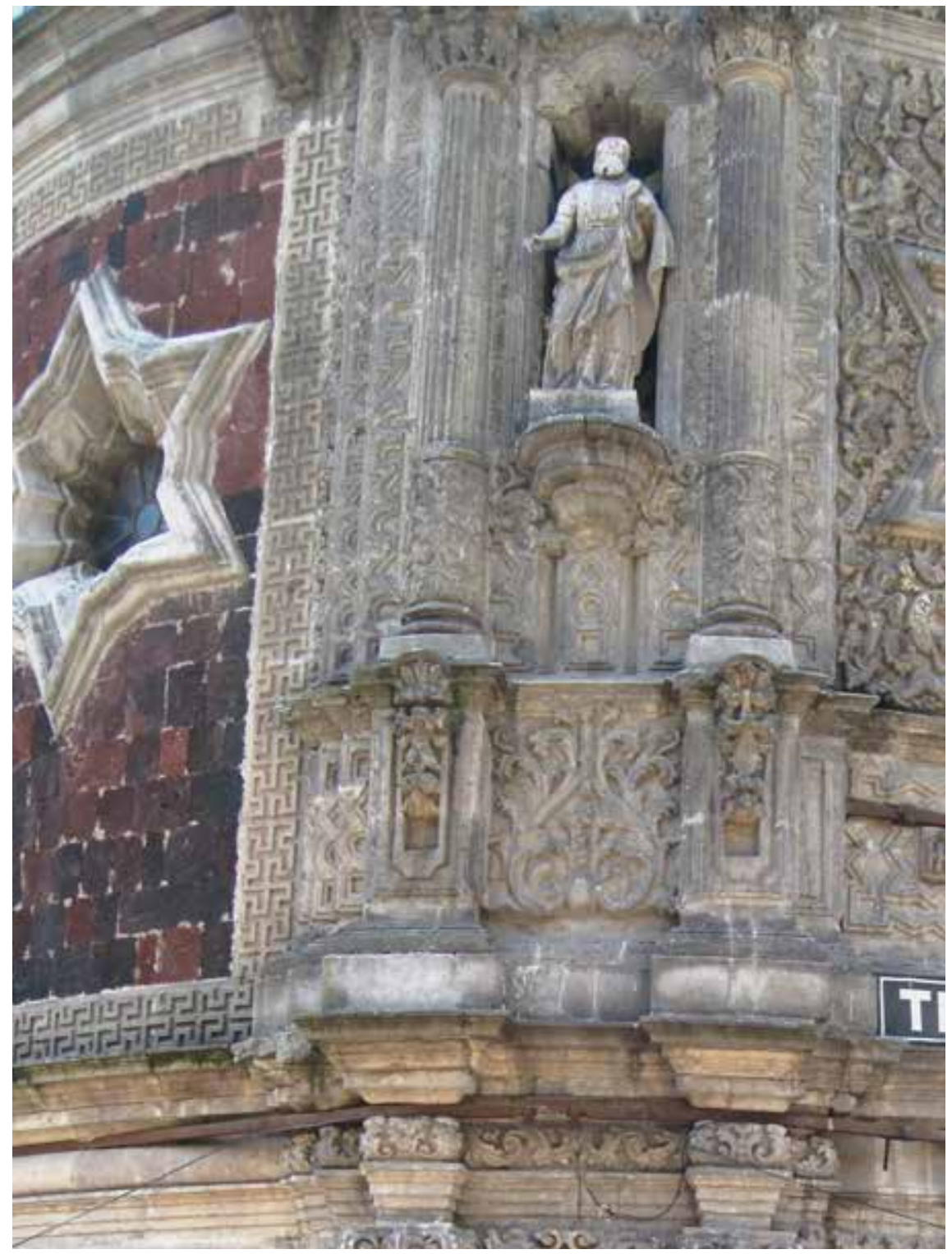

IMAGEN 12: Portada principal de la capilla del Pocito de la Villa de Guadalupe, Ciudad de México. Foto: Martha Fernández 


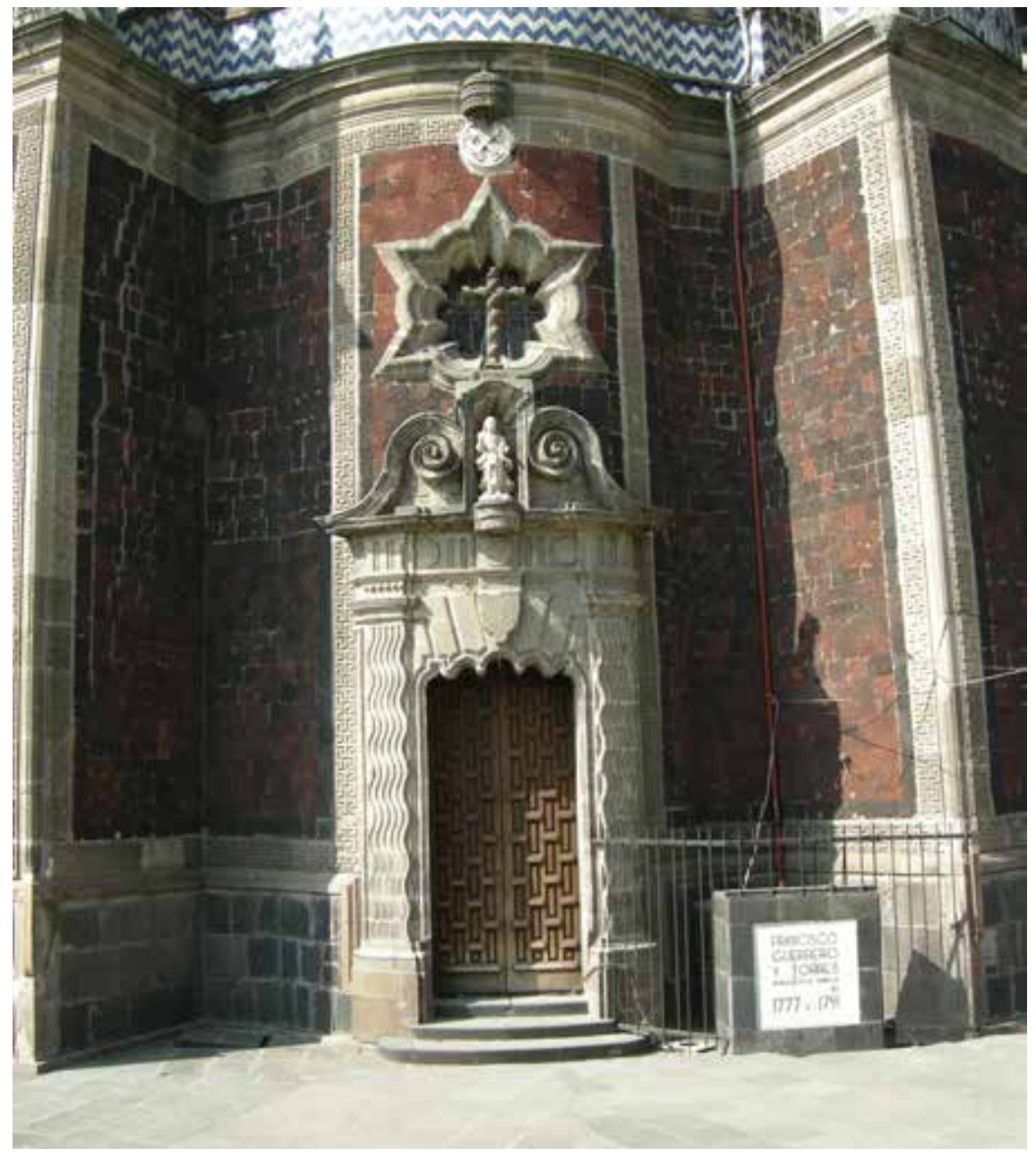

ImAGEN 13: Portada lateral de la capilla del Pocito de la Villa de Guadalupe, Ciudad de México. Foto: Martha Fernández

que "Envuelto de luz como de un manto; / despliegas los cielos como una tienda..." Ambas citas se refieren a la tienda cósmica, entendida esta como la cubierta de la Tierra, su techo; idea que fue asimilada por el cristianismo a través de la cultura grecolatina, la cual también desarrolló el concepto de un Dios, Coelus, cuya función era extender el manto curvo del cielo, como expliqué en otro estudio (Fernández 2017: 71-87). De esta forma, los cortinajes vuelven a la idea de que las ventanas son la imagen del cielo o se abren a él, más aún en las portadas cuyos vanos tienen precisamente la forma de una 


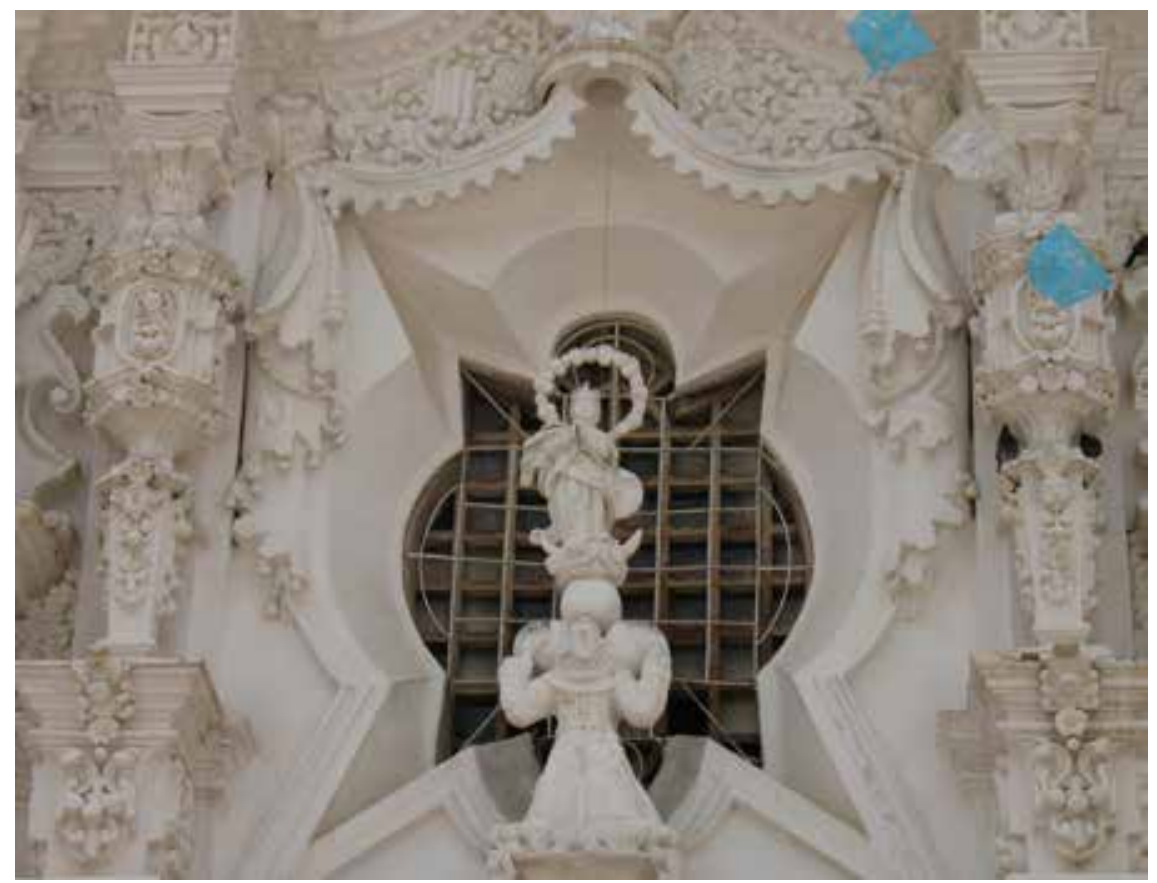

IMAGEN 14: Transparente de la portada principal del santuario de Nuestra Señora de Ocotlán, Tlaxcala. Foto: Martha Fernández

estrella, pero en este caso, el cielo, son los templos mismos convertidos en la imagen de la Jerusalén celestial, cuya luz forma una mandorla simbólica alrededor de las imágenes colocadas frente a ellas.

\section{Transparentes y camarines}

Una vez que hemos comprendido que tanto la ciudad como los templos novohispanos eran considerados como la Jerusalén celestial en la tierra, será sencillo establecer la vinculación con los transparentes que se abrieron hacia los camarines, otro espacio interior, localizados detrás de los retablos mayores. Los camarines eran y, en general, todavía son, espacios reservados para actividades relacionadas con el culto a la imagen titular de la iglesia o capilla donde se abrieron. Cuando se trata de imágenes marianas, también fungen como lugares donde se "viste" a la Virgen, ya sea cuando simplemente cambia de vestuario o cuando se "arregla" para salir en procesión. Ahí se 
guardan sus joyas, sus capas, sus coronas y, por supuesto, sus ropajes. En la época de esplendor del arte barroco se abrieron camarines tan lujosos como los propios templos, cubiertos de ornamentación pintada, como el de la capilla del Rosario del convento dominico de Azcapotzalco, ${ }^{34}$ en la Ciudad de México (imagen 15), en yesería como la que podemos ver en el camarín del santuario de Nuestra Señora de Ocotlán, en Tlaxcala, ${ }^{35}$ o con retablos, como el de la Inmaculada Concepción de la iglesia de San Diego en Aguascalientes. ${ }^{6}$

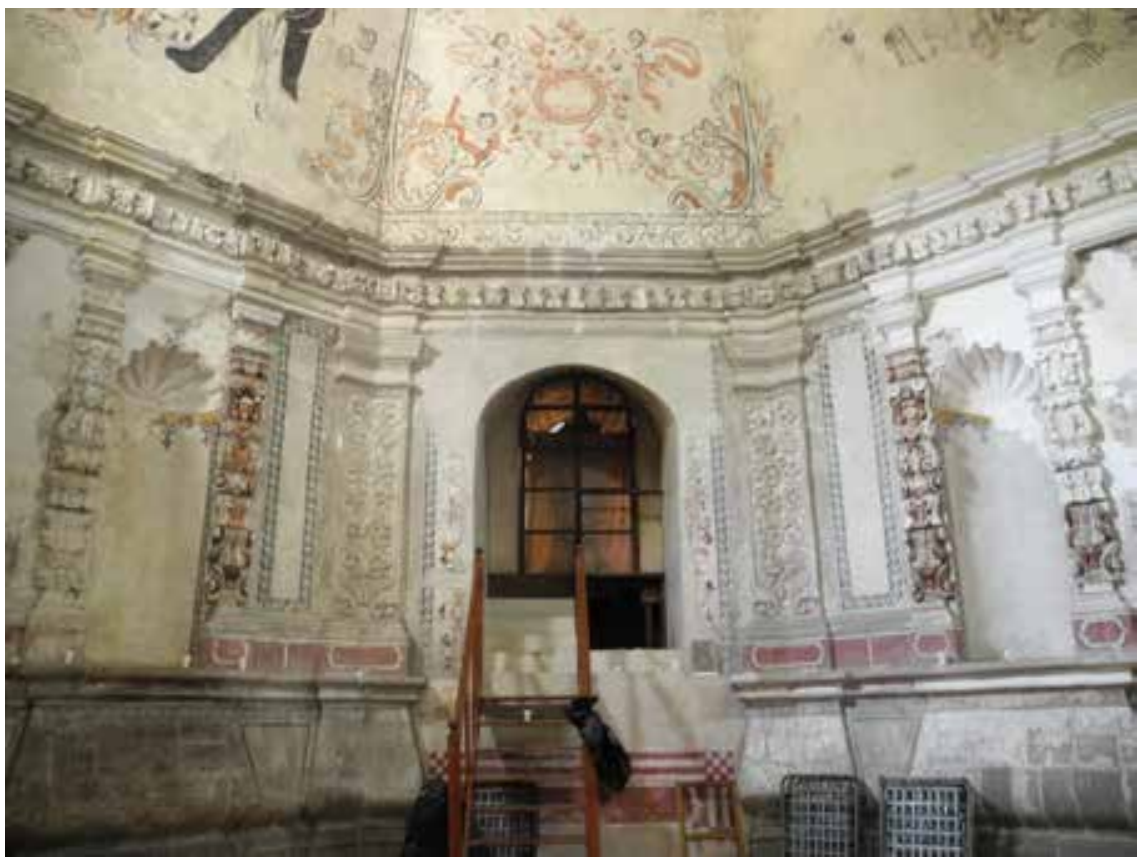

IMAGEN 15: Camarín de la capilla de la Virgen del Rosario, iglesia de los apóstoles San Felipey Santiago, Azcapotzalco, Ciudad de México. Foto: Martha Fernández

34 En el arco del coro de la capilla del Rosario existe una inscripción con la fecha de 20 de enero de 1720. El camarín pudo ser más o menos contemporáneo a ella.

35 Construido en el siglo XVIII.

36 Construido por el arquitecto Santiago Medina de 1792 a 1797. En el propio camarín existe una inscripción que reza: "El Mtro S.tiago MEdina DElineo y Construio este Templo a MARIA SSma. Ntra Sra a expensas del Caudal del S. Cptn. Dn JuN Franco Calera", esto es: "El maestro Santiago Medina delineó y construyó este templo a María Santísima Nuestra Señora a expensas del caudal del señor capitán don Juan Francisco Calera”. 
El significado simbólico de su espacio muchas veces tiene que ver con reconstrucciones hipotéticas del Templo de Salomón, sea por su forma octagonal (como el de Azcapotzalco) o por las columnas helicoidales que lucen (como el de Ocotlán), pero por su ornamentación, a base de hojas, palmas, ángeles, flores, conchas, etc., así como representaciones alusivas a la imagen devocional, es claro que simbolizan otro paraíso, otra casa de Dios y de María, otro recinto sagrado. También pueden tener cúpulas con linternillas o ventanas en los muros que facilitan su iluminación desde el exterior; entonces se convierten en espacios que reciben la luz de Dios, física y simbólica, de tres direcciones distintas: del cielo, de la ciudad y de la iglesia, pero ellos mismos emanan su propia luz simbólica al ser en sí mismos otra Jerusalén celestial.

Por desgracia, muchos de esos camarines perdieron su ornamentación, como es el caso del de la capilla del Rosario del convento agustino de la Inmaculada Concepción, en Zacualpan de Amilpas, estado de Morelos. ${ }^{37}$ Pero eso no quiere decir que hayan perdido el significado simbólico de sus espacios y de sus transparentes.

\section{Conclusión}

Como afirma Mircea Eliade, el hombre no puede vivir más que en un espacio sagrado, por lo que explica que, "cuando este espacio no se revela a través de una hierofanía, el hombre lo construye aplicando los cánones cosmológicos y geománticos". Esto lo califica el autor como una "nostalgia del paraíso", la necesidad del hombre por estar siempre "en el corazón del mundo, de la realidad y de la sacralidad y de superar en sí mismo de una manera natural la condición humana y recobrar la condición divina, o como un cristiano diría: la condición anterior a la caída" (Eliade 2000: 540).

La sociedad novohispana hizo posible esa aspiración convirtiendo sus ciudades y pueblos, así como sus templos y capillas en reproducciones de la Jerusalén celestial, por lo que, al utilizar los transparentes, simplemente la hicieron visible por medio del manejo de la luz. La luz de Dios que entraba al recinto sagrado, al mismo tiempo que emanaba de él. En concreto, los transparentes fueron la imagen tangible de "la Casa de Dios y la puerta del cielo".

37 En la espadaña que se encuentra sobre el techo del camarín, prácticamente adosada a la cúpula de la capilla, se encuentra inscrita la fecha de 1782 . 


\section{Bibliografía}

Angulo ÍñIguez, Diego, y Enrique Marco DorTa (1945-1950). Historia del arte hispanoamericano, 3 vols., Barcelona, Salvat Editores.

Armstrong, Karen (1997). Jerusalén. Una ciudad tres religiones, traducción de Ramón Alonso Díez Aragón y María del Carmen Blanco Moreno. Barcelona, Paidós.

Bazarte Martínez, Alicia, Enrique Tovar Esquivel y Martha A. Tronco Rosas (2001). El convento jerónimo de San Lorenzo (1598-1867), México, Instituto Politécnico Nacional/Secretaría de Educación Pública.

Bermúdez de Castro, Diego Antonio (1985). Theatro Angelopolitano o Historia de la ciudad de la Puebla, ed. facsimilar de la de 1746, Puebla, Junta de Mejoramiento Moral, Cívico y Material del Municipio de Puebla.

Borromeo, Carlos (1985). Instrucciones de la fábrica y ajuar eclesiásticos. Introducción, traducción y notas de Bulmaro Reyes Coria, nota preliminar de Elena Isabel Estrada de Gerlero, México, Universidad Nacional Autónoma de México, Instituto de Investigaciones Estéticas, Imprenta Universitaria (Estudios y Fuentes del Arte en México, XLIX). Publicada por primera ocasión en 1577.

Cabrera y Quintero, Cayetano (1981). Escudo de Armas de México, escrito por el presbítero...para conmemorar el final de la funesta epidemia de matlazahuatl que asoló a la Nueva España entre 1736 y 1738, ed. fascimilar de la de 1746, con un estudio histórico y una cronología Víctor M. Ruiz Naufal. México, Instituto Mexicano del Seguro Social.

Eliade, Mircea (200o). Tratado de historia de las religiones. Morfología y dialéctica de lo sagrado, $3^{\underline{a}}$ ed. Traducción A. Medinaveitia. Madrid, Ediciones Cristiandad.

EstebAn LoREnte, Juan Francisco (1998). Tratado de iconografía. Madrid, Istmo.

Fernández de Echeverría, Mariano (1820). Baluartes de México. Historia de las cuatro milagrosas imágenes de la Virgen María, que se veneran en la Muy Noble, Leal e Imperial Ciudad de México, capital de la Nueva España, a los cuatro vientos principales, en sus extramuros, y de sus magníficos santuarios, con otras particularidades, obra póstuma. Dada a la luz en R. P. Fray Antonio María de San José, carmelita descalzo, México, Imprenta de D. Alejandro Valdés.

FERNÁNDEZ, Martha (1985). Arquitectura y gobierno virreinal. Los maestros mayores de la ciudad de México. Siglo XVII. México, Universidad Nacional Autónoma de México, Instituto de Investigaciones Estéticas. (Estudios y Fuentes del Arte en México, XLV).

FERNÁNDEZ, Martha (2011 a). "La luz en la arquitectura barroca novohispana”, en Martha Fernández, Estudios sobre el simbolismo en la arquitectura novohispana. México, Universidad Nacional Autónoma de México/Instituto de Investigaciones Estéticas/Instituto Nacional de Antropología e Historia: 159-186.

FERNÁNDEZ, Martha (2011 b). "El significado simbólico del retablo novohispano", en Estudios sobre el simbolismo en la arquitectura novohispana. México, Universidad Nacional Autónoma de México/Instituto de Investigaciones Estéticas/Instituto Nacional de Antropología e Historia: 305-328.

FERNÁNDEZ, Martha (2011 c). "El retablo barroco. Sus tipologías y su mensaje simbólico”, en Estudios sobre el simbolismo en la arquitectura novohispana. México, 
Universidad Nacional Autónoma de México/Instituto de Investigaciones Estéticas/ Instituto Nacional de Antropología e Historia: 329-364.

Fernández, Martha (2015 a). "El proyecto de Claudio de Arciniega", en Catedral de México, $2^{\underline{a}}$ ed. México, Consejo Nacional para la Cultura y las Artes/Gobierno de la República: 97-103.

FERnÁNDEZ, Martha (2015b). "El rediseño de la Catedral”, en Catedral de México, 2ª ed. México, Consejo Nacional para la Cultura y las Artes/ Gobierno de la República: 123-139.

FERNÁNDEZ, Martha (2017): "La imagen de la tienda cósmica en los santuarios del Tepeyac”, Interpretatio. Revista de Hermenéutica, vol. 1, núm. 2: 71-87.

Florencia, fray Francisco de (1785). "La Estrella del Norte de México, aparecida al rayar el día de la luz Evangélica en este Nuevo Mundo, en la cumbre del cerro del Tepeyac, orilla del mar Tezcucano, a un natural recién convertido; pintada tres días después milagrosamente en su Tilma o Capa de Lienzo delante del Obispo y de su familia, en su Casa Obispal, para luz de la Fe de los Indios; para rumbo cierto a los Españoles en la virtud, para serenidad de las tempestuosas inundaciones de la Laguna” [1688], en Historia de la milagrosa imagen de Nuestra Señora de Guadalupe de México, que se apareció en la Manta de Juan Diego, Madrid, Imprenta de Lorenzo de San Martín, Impresor de la Secretaría de Estado y del Despacho Universal de Indias, y de otras varias oficinas de S. M. Año de 1785.

GARcíA, Ana Lorenia (2004). "Capilla del Salto del Agua”, en Armando Ruiz (coordinador editorial), Arquitectura religiosa de la Ciudad de México. Siglos XVI al XX. Una guía. México, Asociación del Patrimonio Artístico Mexicano/Secretaría de Cultura/Secretaría de Turismo/Fondo Mixto de Promoción Turística del Gobierno del Distrito Federal.

GARCía MARTÍnez, Ana Lorenia (2005). "La vanguardia americana. Tradición arquitectónica novohispana y modelos importados en la arquitectura de la segunda mitad del siglo XVIII: el caso de la iglesia de Nuestra Señora de Loreto, ciudad de México". Tesis de Maestría en Historia del Arte, Universidad Nacional Autónoma de México.

GonZÁlez-Polo y Acosta, Ignacio (2006): "Vida y obra del arquitecto Francisco Antonio Guerrero y Torres (1727-1792)". Tesis de Doctorado en Historia, México, Facultad de Filosofía y Letras, Universidad Nacional Autónoma de México.

HANI, Jean (200o). El simbolismo del Templo cristiano. Traducción Jordi Quingles. Palma de Mallorca, José J. de Olañeta, editor.

Halcón, Fátima (2012). Felipe de Ureña. La difusión del estípite en Nueva España. Sevilla, Universidad de Sevilla/Secretariado de Publicaciones.

MArroqui, José María (1903). La ciudad de México. Contiene: el origen de los nombres de muchas de sus calles y plazas, del de varios establecimientos públicos y privados, y no pocas noticias curiosas y entretenidas. 3 vols., México, Tip. y Lit. "La Europea”.

MARTín GonzÁLEz, Juan José. (1995). "Avance de una tipología del retablo barroco”, Imafronte. El retablo español, 3-4-5, Universidad de Murcia.

Nácar Fuster, Eloíno, y Alberto Colunga O. P. (1964). Sagrada Biblia. Versión directa de las lenguas originales. Madrid, Biblioteca de Autores Cristianos. 
NÁjERA y Enciso, Juan Antonio de (1755). Altar mystico de Jesús y María Santíssima en su Natividad. Sermón panegyrico que predicó D. Juan Antonio de Naxera y Enzisso ... en la Iglesia del Religiosíssimo Convento de Nuestra Señora de Regina Coeli de esta Ciudad de México, el día ocho de septiembre, en que se celebra la Natividad de María Santíssima, su Titular, expuesto a la pública veneración el Augustíssimo Sacramento, y con la ocurrencia de haberse estrenado una muy preciosa Custodia, y haberse dedicado el mismo día un pulido Retablo que consteó la magnificencia de la Ilustre Cofradía de el Santo Ecce Homo, que está al cuidado de los Mercaderes: á cuyas expensas sale á luz, y por mano del Author lo dedican al Illmo. Sr. Dr. D. Manuel Joseph Rubio y Salinas. Con Licencia de los Superiores. En la Imprenta Nueva de la Biblioteca Mexicana. Año de 1755.

RAmírez, Juan Antonio (2003). Edificios-cuerpo. Cuerpo humano y arquitectura: analogías, metáforas, derivaciones. Madrid, Ediciones Siruela.

RAmírez Montes, Mina (2005). Niñas, doncellas, vírgenes eternas. Santa Clara de Querétaro (1607-1864). México, Universidad Nacional Autónoma de México/ Instituto de Investigaciones Estéticas (Estudios y Fuentes del Arte en México, 49).

Sánchez, Miguel (1648). Imagen de la Virgen María Madre de Dios de Guadalupe. Milagrosamente aparecida en la ciudad de México. Celebrada en su historia, con la profecía del capítulo doce del Apocalipsis. México, Imprenta de la Viuda de Bernardo Calderón. Año de 1648.

Torre Villar, Ernesto de la, y Ramiro NaVArro de ANDA (1999). Testimonios históricos guadalupanos. $2^{\underline{a}}$ ed. México, Fondo de Cultura Económica.

Toussaint, Manuel (1973). La Catedral de México y el Sagrario Metropolitano. Su historia, su tesoro, su arte, $2^{\underline{a}}$ ed., México, Editorial Porrúa.

Tovar de Teresa, Guillermo (1988). Bibliografía novohispana de arte, 2 vols. Prólogo José Pascual Buxó. México, Fondo de Cultura Económica.

Tovar de Teresa, Guillermo (1995). Repertorio de artistas en México. Artes plásticas y decorativas, 3 vols. México, Grupo Financiero Bancomer.

VARgas Lugo, Elisa (1986). Las portadas religiosas de México. México, Instituto de Investigaciones Estéticas, Universidad Nacional Autónoma de México.

\section{Martha Fernández}

Doctora en Historia del Arte por la Universidad Nacional Autónoma de México, investigadora del Instituto de Investigaciones Estéticas de la UNAM, profesora en la Facultad de Filosofía y Letras y en la División de Estudios de Posgrado de la misma universidad. Miembro del Sistema Nacional de Investigadores, de la Academia Mexicana de Ciencias y del Comité Mexicano del Icomos. Entre sus publicaciones pueden mencionarse Estudios sobre el simbolismo en la arquitectura novohispana, La imagen del Templo de Jerusalén la Nueva España y Cristóbal de Medina Vargas y la arquitectura salomónica en la Nueva España durante el siglo XVII. 